\title{
Article \\ Effects of Al or Mo Addition on Microstructure and Mechanical Properties of Fe-Rich Nonequiatomic FeCrCoMnNi High-Entropy Alloy
}

\author{
Shuliang Wang ${ }^{1,2, *}$, Luyu Chen ${ }^{1}$, Qilin Li $^{1}$, Shidong Wang ${ }^{2, * \mathbb{D}}$, Mingyu Wu ${ }^{2,3}$, Shuiyuan Yang ${ }^{4}$ \\ and Dinghan Xiang ${ }^{5}$
}

Citation: Wang, S.; Chen, L.; Li, Q.; Wang, S.; Wu, M.; Yang, S.; Xiang, D. Effects of $\mathrm{Al}$ or Mo Addition on Microstructure and Mechanical Properties of Fe-Rich Nonequiatomic FeCrCoMnNi High-Entropy Alloy. Metals 2022, 12, 191. https://doi.org/ $10.3390 /$ met12020191

Academic Editor: Oleg Mishin

Received: 20 November 2021

Accepted: 19 January 2022

Published: 20 January 2022

Publisher's Note: MDPI stays neutral with regard to jurisdictional claims in published maps and institutional affiliations.

Copyright: (c) 2022 by the authors. Licensee MDPI, Basel, Switzerland. This article is an open access article distributed under the terms and conditions of the Creative Commons Attribution (CC BY) license (https:// creativecommons.org/licenses/by/ $4.0 /)$.
1 School of New Energy and Materials, Southwest Petroleum University, Chengdu 610500, China; cly9248@163.com (L.C.); lq1517680544@163.com (Q.L.)

2 Department of Chemical and Materials Engineering, University of Alberta, Edmonton, AB T6G 2G6, Canada; mingyu8@ualberta.ca

3 School of Materials Science and Engineering, Shanghai University, 149 Yanchang Road, Shanghai 200072, China

4 College of Materials, Xiamen University, Xiamen 361005, China; yangshuiyuan@xmu.edu.cn

5 Guangxi Key Laboratory of Information Materials, Guilin University of Electronic Technology, Guilin 541004, China; xiangdinghan@163.com

* Correspondence: wsliang1465@126.com (S.W.); shidong@ualberta.ca (S.W.)

\begin{abstract}
In this work, a Fe-rich nonequiatomic $\mathrm{Fe}_{40} \mathrm{Cr}_{15} \mathrm{Co}_{15} \mathrm{Mn}_{10} \mathrm{Ni}_{20}$ high-entropy alloy was successfully prepared based on phase analysis and cost reduction. $\mathrm{Fe}_{40} \mathrm{Cr}_{15} \mathrm{Co}_{15} \mathrm{Mn}_{10} \mathrm{Ni}_{20}$ high-entropy alloy with a single-phase face-centered cubic (FCC) structure was strengthened by the addition of 11 at.\% $\mathrm{Al}$ or 10 at.\% Mo, and the variations of phase and mechanical properties of the strengthened alloys were subsequently investigated. It has been found that the addition of 11 at.\% $\mathrm{Al}$ led to the formation of FCC and body-centered cubic (BCC) dual-phase structure in the $\mathrm{Fe}_{40} \mathrm{Cr}_{15} \mathrm{Co}_{10} \mathrm{Mn}_{4} \mathrm{Ni}_{20} \mathrm{Al}_{11}$ alloy, while its yield strength $\left(\sigma_{0.2}\right)$ and tensile strength increased from $158 \pm 4 \mathrm{MPa}$ and $420 \pm 20 \mathrm{MPa}$ to $218 \pm 7 \mathrm{MPa}$ and $507 \pm 16 \mathrm{MPa}$, respectively, as compared to the single-phase FCC structure $\mathrm{Fe}_{40} \mathrm{Cr}_{15} \mathrm{Co}_{15} \mathrm{Mn}_{10} \mathrm{Ni}_{20}$ alloy. The addition of 10 at.\% Mo introduced intermetallic compounds of $\mu$ and $\sigma$ phases, which resulted in improved yield strength of $246 \pm 15 \mathrm{MPa}$ for the $\mathrm{Fe}_{40} \mathrm{Cr}_{15} \mathrm{Co}_{10} \mathrm{Mn}_{5} \mathrm{Ni}_{20} \mathrm{Mo}_{10}$ alloy. However, the alloy exhibited premature brittle fracture due to the existence of a large number of intermetallic compounds, which led to deteriorated tensile strength of $346 \pm 15 \mathrm{MPa}$. The findings of this work suggest that the introduced secondary phases by the addition of $\mathrm{Al}$ and Mo can effectively strengthen the high-entropy alloy; however, the number of intermetallic compounds should be controlled to achieve a combination of high strength and good ductility, which provides a reference for the follow-up study of nonequiatomic high-entropy alloys.
\end{abstract}

Keywords: nonequiatomic; high-entropy alloys; microstructure; phase transition; mechanical properties

\section{Introduction}

The design and research of traditional alloys have long been limited to the idea of using one or two principal elements as the matrix which is supplemented with additional minor elements to adjust the performance [1-4]. The traditional alloy design concept was challenged since the design concept of high-entropy alloy (HEA) was proposed and the HEA was successfully prepared. Conventional wisdom holds that high-entropy alloys (HEAs) consist of five or more principal elements with each contributing 5 at. $\%$ to 35 at.\%, usually at an equal atomic ratio or near equal atomic ratio [5-9]. The mixing entropy of the solid solution phase in the high-entropy alloy is much higher than that of the intermetallic compound at elevated temperatures. Therefore, it is easier to form a simple solid solution phase, such as the face-centered cubic (FCC) phase and body-centered cubic (BCC) phase [10-14]. In addition, high-entropy alloys also have delayed diffusion and 
lattice distortion effects, which provides high-entropy alloys with great corrosion resistance, remarkable radiation resistance, outstanding mechanical properties, and good thermal stability $[15,16]$. Therefore, high-entropy alloys such as the FeCrCoMnNi, MoNbTaVW, $\mathrm{Al}_{\mathrm{x}} \mathrm{CrCuFeNi}$, and $\mathrm{CoCrCuFeNiTi}$ systems have received extensive attention from both industry and academia [17-25]. Among them, the FeCrCoMnNi high-entropy alloy, which was first proposed by Cantor et al. [26], has been widely studied because of its prominent ductility as a result of its single-phase FCC structure. However, the drawback of the FeCrCoMnNi system high-entropy alloy is its poor strength $[27,28]$, which attracts extensive attention for strengthening the alloy. Nowadays, the addition of $\mathrm{Al}$, Mo, and other elements to introduce secondary phases into the FCC-structured matrix is a common way to strengthen the high-entropy alloy. For instance, He et al. [29] introduced the BCC phase in FeCrCoMnNi high-entropy alloy by adding Al, and Shun et al. [30] introduced intermetallic compounds in CoCrFeNi high-entropy alloy by adding Mo, both of which effectively strengthened the single-phase FCC matrix. Even though the research on high-entropy alloys was focused on the equal or near-equal atomic ratio design concept in the initial years, more attention has been paid to the nonequiatomic approach recently [31-34]. It is reported that Tasan et al. [35] successfully prepared a nonequiatomic $\mathrm{Fe}_{40} \mathrm{Mn}_{27} \mathrm{Ni}_{26} \mathrm{Co}_{5} \mathrm{Cr}_{2}$ high-entropy alloy which exhibited comparable mechanical properties to those with equal atomic ratio. Later on, Bae et al. prepared nonequiatomic CoCrFeNiMo high-entropy alloys with different Mo content, which strengthened the single-phase FCC matrix by precipitation strengthening of the $\mu$-phase [36].

For the design of nonequiatomic high-entropy alloys, each element component has a unique effect on the phase structure of FeCrCoMnNi system alloys. Many researchers reported that reducing the content of $\mathrm{Cr}$ and $\mathrm{Mn}$ to a suitable level is beneficial to avoid the appearance of the $\sigma$ phase and improve the stability of the FCC phase [37,38]. At the same time, many views suggest that properly increasing Co and Ni will not only assist the formation of the FCC phase but also inhibit the appearance of the secondary phases $[39,40]$. Additionally, it proves that the effect of $\mathrm{Ni}$ and Co contents on the formation of the FCC phase is similar and $\mathrm{Ni}$ has a stronger ability to form the FCC phase comparing to that of Co $[41,42]$. Moreover, the traditional design concept of high-entropy alloy with the content of each element being within $5-35 \%$ is not necessarily required using the nonequiatomic design approach [43]. To reduce the cost, the content of non-precious metal Fe can be increased, and the proportion of precious metal Co is reduced by using Ni with a relatively low price and a similar effect instead. The content of $\mathrm{Cr}$ can also be reduced as long as it meets the requirement for the corrosion resistance of stainless steels.

The contents of Al and Mo are critical to the strengthening of the FCC-structured high-entropy alloy. For the Al element, it has been found that the BCC phase will appear with an increase of the content of $\mathrm{Al}$ in the single-phase FCC structure FeCrCoMnNi high-entropy alloy, whereas the formation of a brittle ordered-phase B2 can occur with further increase of the $\mathrm{Al}$ content [44]. Rao et al. performed thermodynamic calculations on $\mathrm{Al}_{\mathrm{x}} \mathrm{CoCrFeNi}$ alloys in the temperature range of $200-1500{ }^{\circ} \mathrm{C}$ [45]. The results showed that the temperature range in which the B2 phase could exist was $200-1350{ }^{\circ} \mathrm{C}$ when the $\mathrm{Al}$ content was high (i.e., $\mathrm{x}=0.7$ ). In the presence of the $\mathrm{B} 2$ phase, the plasticity of the alloy severely deteriorated (the elongation at fracture was only $7 \%$ ), even though its tensile strength could be enhanced [45]. Joseph et al. reported a similar phenomenon by tensile testing $\mathrm{B} 2$-phase-containing $\mathrm{Al}_{\mathrm{x}} \mathrm{CoCrFeNi}$ alloys, in which brittle fracture was found, indicating the detrimental effect of the B2 phase on the tensile properties of the highentropy alloys [46]. Thus, it is wise to prevent the formation of the B2 phase while using the $\mathrm{BCC}$ phase as the strengthening phase. Aizenshtein et al. found that the B2 phase appeared in $\mathrm{Al}_{\mathrm{x}} \mathrm{CoCrFeNi}$ alloys with a measured $\mathrm{Al}$ content of 11.5 at.\% [47]. However, Wang et al. reported that the $\mathrm{Al}_{x} \mathrm{CoCrFeNi}$ alloy was still $\mathrm{FCC}+\mathrm{BCC}$ structure without the $\mathrm{B} 2$ phase at the measured $\mathrm{Al}$ content of 11.0 at.\% [48]. It suggested that the B2 phase can hardly form when the $\mathrm{Al}$ content is $\leq 11.0$ at. $\%$. Regarding the Mo element, phase transformation is in the sequence of $\mathrm{FCC} \rightarrow \mathrm{FCC}+\sigma \rightarrow \mathrm{FCC}+\sigma+\mu$ when increasing the content of Mo in the 
FeCrCoMnNi high-entropy alloys, in which $\sigma$ and $\mu$ phases are two different intermetallic compounds [49]. The $\sigma$ phase tends to completely transform into $\mu$ phase when further increasing the content of Mo, contributing to an (FCC $+\mu)$-structured alloy, which is consistent with the thermodynamic calculation results by Bae et al. [36]. Shun et al. reported that the strengthening effect of the intermetallic compound $\mu$ was approximately two times higher than that of the intermetallic compound $\sigma$ on the compressive yield strength of the $\mathrm{CoCrFeNiMo}$ high-entropy alloys [30]. Liu et al. found that the compressive yield strength increased from $200 \mathrm{MPa}$ to $300 \mathrm{MPa}$ by the solid solution strengthening and intermetallic compound strengthening when the Mo content was increased [50]. However, the formation of intermetallic compound $\mu$ when further increasing the Mo content could increase the compressive yield strength to $\sim 1000 \mathrm{MPa}$. Through thermodynamic calculations, Liu et al. reported that the CoCrFeNiMo alloy was composed of FCC $+\sigma+\mu$ at the Mo content of 5.44 at.\% [51]. Wu et al. performed thermodynamic calculations on $\mathrm{CoCrFeNiMo}$ alloys at $900{ }^{\circ} \mathrm{C}$ and found that the intermetallic compounds $\mu$ together with FCC matrix existed when the Mo content was close to $10 \%$ and the $\mathrm{Cr}$ content was as high as $15 \%$ [49]. These findings are consistent with the experimental work by Ming et al. who determined the disappearance of intermetallic compounds $\sigma$ when the Mo content was increased to 10 at.\% for the $\mathrm{CoCrFeNiMo}$ alloys [6]. Based on the above analysis, the content of $\mathrm{Al}$ could be controlled at $~ 11$ at.\% to introduce sufficient strengthening-phase BCC while preventing the formation of brittle B2 phase. The content of the Mo element could be controlled at 10 at. $\%$ to make sure the $\sigma$ phase is completely transformed into the $\mu$ phase to fully utilize the strengthening effect of the latter on the yield strength. Moreover, the research on the tensile properties of single- $\mu$-phase-containing high-entropy alloys is scarcely found even though their compressive properties are commonly reported [30,50]. The addition of $\mathrm{Al}$ or Mo will inevitably reduce the contents of other elements in the alloy. As suggested above, the precious metal Co could be reduced by using $\mathrm{Ni}$ with a relatively low price and a similar effect for the stability of the FCC phase instead. The element Mn can easily burn during the melting process and it is detrimental to the stability of the FCC phase [38]. Therefore, priority should be given to reducing the contents of Co and Mn while keeping the content of $\mathrm{Fe}, \mathrm{Cr}$, and $\mathrm{Ni}$ unchanged for the addition of the $\mathrm{Al}$ and $\mathrm{Mo}$ to strengthen the prepared high-entropy alloys.

Based on the literature review and analysis, it is convincing that the preparation of the nonequiatomic $\mathrm{FeCrCoMnNi}$ system alloys with a high content of $\mathrm{Fe}$ and a low content of $\mathrm{Cr}, \mathrm{Co}$, and $\mathrm{Mn}$ is highly possible and cost-efficient. The aim of this investigation is therefore proposed as follows: (1) Try to experimentally prove it is feasible to prepare Fe-rich nonequiatomic FeCrCoMnNi single-phase FCC-structured high-entropy alloys; if so, the preparation of the alloys with a high content of $\mathrm{Fe}$ (for instance $40 \%$ ) and a low content of $\mathrm{Cr}, \mathrm{Co}$, and Mn would reduce the cost. (2) Strengthening studies will be conducted using $\mathrm{Al}$ and Mo for the cost-efficient Fe-rich nonequiatomic $\mathrm{FeCrCoMnNi}$ alloys. However, the investigations on the preparation and characterization of Fe-rich nonequiatomic $\mathrm{FeCr}$ CoMnNi single-phase high-entropy alloys and the strengthening studies with the addition of $\mathrm{Al}$ and $\mathrm{Mo}$, which is critical to the follow-up research of cost-efficient nonequiatomic high-entropy alloys, are scarcely reported.

In this investigation, a Fe-rich nonequiatomic $\mathrm{Fe}_{40} \mathrm{Cr}_{15} \mathrm{Co}_{15} \mathrm{Mn}_{10} \mathrm{Ni}_{20}$ high-entropy alloy was successfully prepared based on the above phase analysis and the cost reduction, and then 11 at.\% $\mathrm{Al}$ or 10 at.\% Mo was added on this basis to obtain the strengthened $\mathrm{Fe}_{40} \mathrm{Cr}_{15} \mathrm{Co}_{10} \mathrm{Mn}_{4} \mathrm{Ni}_{20} \mathrm{Al}_{11}$ or $\mathrm{Fe}_{40} \mathrm{Cr}_{15} \mathrm{Co}_{10} \mathrm{Mn}_{5} \mathrm{Ni}_{20} \mathrm{Mo}_{10}$ nonequiatomic high-entropy alloys. The effect of $\mathrm{Al}$ or Mo on the microstructure, Vickers hardness and tensile properties of the $\mathrm{Fe}_{40} \mathrm{Cr}_{15} \mathrm{Co}_{15} \mathrm{Mn}_{10} \mathrm{Ni}_{20}$ alloy was investigated by metallographic microscope, $\mathrm{X}$-ray diffractometer (XRD), scanning electron microscope (SEM), Vickers hardness tester, and universal testing machine. The variations of microstructure and mechanical properties were analyzed, which could provide a reference for the follow-up study of nonequiatomic high-entropy alloys. 


\section{Materials and Methods}

\subsection{Materials}

$\mathrm{Fe}_{40} \mathrm{Cr}_{15} \mathrm{Co}_{15} \mathrm{Mn}_{10} \mathrm{Ni}_{20}, \mathrm{Fe}_{40} \mathrm{Cr}_{15} \mathrm{Co}_{10} \mathrm{Mn}_{4} \mathrm{Ni}_{20} \mathrm{Al}_{11}$, and $\mathrm{Fe}_{40} \mathrm{Cr}_{15} \mathrm{Co}_{10} \mathrm{Mn}_{5} \mathrm{Ni}_{20} \mathrm{Mo}_{10}$ high-entropy alloys were prepared by melting and casting in an intermediate frequency induction furnace. The purity of all raw materials was $\geq 99.9 \%$. Mo and $\mathrm{Cr}$ were replaced by $\mathrm{MoFe}$ and $\mathrm{CrFe}$ alloys to lower the melting point, and they were washed several times by using 5\% acetic acid solution and ethanol. Before smelting, argon was used to flush the furnace several times and then evacuated to $10^{-1} \mathrm{~Pa}$. Finally, an ingot with a diameter of $55 \mathrm{~mm}$ was obtained. The composition of the cast ingot was analyzed by using an energy dispersive X-ray spectroscopy (EDS) installed on the ZEISS EVO MA15 scanning electron microscope (SEM). Each EDS measurement was conducted on the polished sample surface with an area of $\sim 0.0625 \mathrm{~mm}^{2}(250 \mu \mathrm{m} \times 250 \mu \mathrm{m})$. For each high-entropy alloy, at least six repeated measurements were performed on three polished samples to ensure reliability. The composition of the ingot is shown in Table 1.

Table 1. Ingot composition analysis.

\begin{tabular}{cccccccc}
\hline Element (at.\%) & Fe & Cr & Co & Mn & Ni & Al & Mo \\
\hline $\mathrm{Fe}_{40} \mathrm{Cr}_{15} \mathrm{Co}_{15} \mathrm{Mn}_{10} \mathrm{Ni}_{20}$ & 39.2 & 16.4 & 15.4 & 9.7 & 19.3 & $/$ & $/$ \\
$\mathrm{Fe}_{40} \mathrm{Cr}_{15} \mathrm{Co}_{10} \mathrm{Mn}_{4} \mathrm{Ni}_{20} \mathrm{Al}_{11}$ & 39.0 & 16.7 & 10.1 & 4.1 & 20.0 & 10.1 & $/$ \\
$\mathrm{Fe}_{40} \mathrm{Cr}_{15} \mathrm{Co}_{10} \mathrm{Mn}_{5} \mathrm{Ni}_{20} \mathrm{Mo}_{10}$ & 40.0 & 15.8 & 9.9 & 5.0 & 19.7 & $/$ & 9.6 \\
\hline
\end{tabular}

\subsection{Microstructure Observation and Phase Analysis}

XJP-3C metallurgical microscope, ZEISS EVO MA15 scanning electron microscope (SEM), and energy dispersive X-ray spectroscopy (EDS) were used to analyze the microstructure of the material. The size of the sample for microstructural analysis was $10 \mathrm{~mm} \times 9 \mathrm{~mm} \times 2 \mathrm{~mm}$, and the sample was polished with 400-2000\# sandpaper in turn and then mechanically polished on cloth using diamond paste. $\mathrm{Fe}_{40} \mathrm{Cr}_{15} \mathrm{Co}_{15} \mathrm{Mn}_{10} \mathrm{Ni}_{20}$ alloy was electrolytically etched in a $10 \%$ oxalic acid solution with a $6 \mathrm{~V}$ DC power supply for 40-80 s. Afterwards, the microstructure was observed using an optical microscope and SEM. The other two high-entropy alloys with Al or Mo were etched by aqua regia with a corrosion time of 4-8 s. X Pert PRO MPD X-ray diffractometer (XRD, Cu target, wavelength $\lambda=1.5418 \AA$ ) with a step size of $0.0167^{\circ}$ was used to characterize the phase composition of the high-entropy alloys.

\subsection{Mechanical Properties}

An HVS-1000 digital display microhardness tester was used to measure the Vickers hardness with the testing load of $200 \mathrm{~g}$ and duration at the maximum load of $15 \mathrm{~s}$. The Vickers hardness was obtained by averaging the values of 20 points made on the sample surface with an equal interval of $0.5 \mathrm{~mm}$. A WDW-100E universal testing machine was employed to test the tensile properties of the alloy with the crosshead velocity of $0.25 \mathrm{~mm} / \mathrm{min}$. The gauge length of the tensile samples was $17 \mathrm{~mm}$, and the thickness and width of the gauge were $2 \mathrm{~mm}$ and $3.5 \mathrm{~mm}$, respectively. Note that the strain of the tensile samples was calculated by the recorded crosshead displacement and the gauge length since no extensometer was used during the test. For each condition, three repeated measurements were conducted to ensure reproducibility. After the test, the elongation at fracture (A) and reduction of area $(Z)$ of the fractured samples were measured. The fracture surface of the tensile samples was then observed by using the aforementioned SEM.

\section{Results}

\subsection{X-ray Diffraction}

The XRD patterns of the three high-entropy alloys in the as-cast state are shown in Figure 1. It reveals that the three alloys all contain FCC-structured matrix, i.e., (Fe, Ni) phase, according to the JCPDS card 23-0297. For the $\mathrm{Fe}_{40} \mathrm{Cr}_{15} \mathrm{Co}_{15} \mathrm{Mn}_{10} \mathrm{Ni}_{20}$ alloy, it is 
composed of a single FCC phase (The lattice parameter of the FCC phase, a, is $3.58420 \AA$ ). For the $\mathrm{Fe}_{40} \mathrm{Cr}_{15} \mathrm{Co}_{10} \mathrm{Mn}_{4} \mathrm{Ni}_{20} \mathrm{Al}_{11}$ alloy, weak diffraction peaks of a BCC-structured phase could be detected (JCPDS card 34-0396) besides the FCC phase [52]. The lattice parameter of the FCC matrix for the $\mathrm{Fe}_{40} \mathrm{Cr}_{15} \mathrm{Co}_{10} \mathrm{Mn}_{4} \mathrm{Ni}_{20} \mathrm{Al}_{11}$ alloy, a, is $3.60273 \AA$. For the $\mathrm{Fe}_{40} \mathrm{Cr}_{15} \mathrm{Co}_{10} \mathrm{Mn}_{5} \mathrm{Ni}_{20} \mathrm{Mo}_{10}$ alloy, the diffraction peaks of $\mu$ phase were observed in addition to the FCC phase, which possesses a structure similar to that of rhombohedral $\mathrm{Co}_{7} \mathrm{Mo}_{6}$ phase (JCPDS card 29-0489) [53]. The lattice parameter of the FCC matrix for the $\mathrm{Fe}_{40} \mathrm{Cr}_{15} \mathrm{Co}_{10} \mathrm{Mn}_{5} \mathrm{Ni}_{20} \mathrm{Mo}_{10}$ alloy, a, is $3.60465 \AA$.

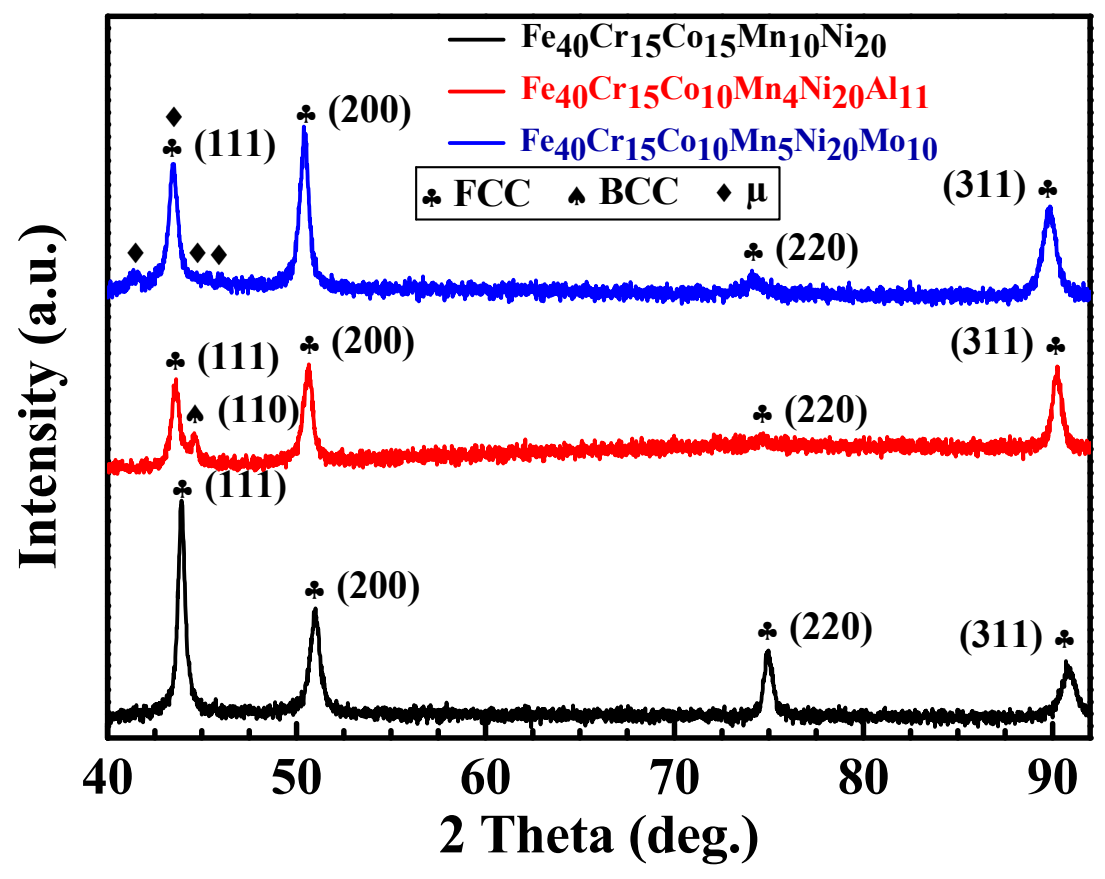

Figure 1. XRD pattern of the three high-entropy alloys.

Compared with the diffraction pattern of the $\mathrm{Fe}_{40} \mathrm{Cr}_{15} \mathrm{Co}_{15} \mathrm{Mn}_{10} \mathrm{Ni}_{20}$ alloy, $\mathrm{Al}$ or $\mathrm{Mo}$ elements cause the diffraction peaks to slightly shift to the left with smaller $2 \theta$ values, as shown in Figure 2. According to Bragg lattice equation (Equation (1) [54]), interplanar spacing $d$ increases with decreasing the incident angle $\theta$ since the wavelength $\lambda$ is constant. It indicates that the addition of Al or Mo element causes the FCC-structured lattice to expand.

$$
2 d \sin \theta=n \lambda(n=1,2,3 \ldots)
$$

The FCC matrix for the $\mathrm{Fe}_{40} \mathrm{Cr}_{15} \mathrm{Co}_{10} \mathrm{Mn}_{4} \mathrm{Ni}_{20} \mathrm{Al}_{11}(3.60273 \AA)$ and $\mathrm{Fe}_{40} \mathrm{Cr}_{15} \mathrm{Co}_{10} \mathrm{Mn}_{5} \mathrm{Ni}_{20}$ $\mathrm{Mo}_{10}\left(3.60465 \AA\right.$ ) alloys both have larger lattice parameter comparing to the $\mathrm{Fe}_{40} \mathrm{Cr}_{15} \mathrm{Co}_{15} \mathrm{Mn}_{10}$ $\mathrm{Ni}_{20}$ alloy (3.58420 $\AA$ ), as indicated by the above XRD analyses. This lattice expansion phenomenon is caused by the fact that the atomic radii of $\mathrm{Al}(1.43 \AA)$ and $\mathrm{Mo}(1.39 \AA)$ are larger than those of other base elements (Fe (1.26 $\AA), \operatorname{Cr}(1.28 \AA), \operatorname{Co}(1.25 \AA), \operatorname{Mn}(1.26 \AA)$, and $\operatorname{Ni}(1.24 \AA))[30,55]$.

The lattice parameters can also be calculated by Vegard's law, which is an approximate empirical rule for solid solution lattice parameter calculation, as shown in Equation (2) [56]:

$$
a_{c a l}=\sum c_{i} a_{i}
$$

where $a_{c a l}$ is the calculated lattice parameter; $c_{i}$ is the molar percentage; and $a_{i}$ is the lattice constant of each composition. The molar percentage for each composition can be obtained by EDS results (Tables 2-4). The lattice constant of each composition $\left(a_{i}\right)$

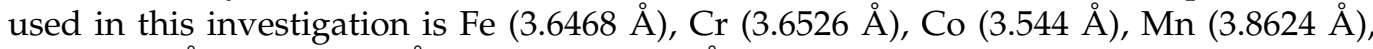
Ni (3.5238 $\AA$ ), Al (4.0495 $\AA$ ), and Mo (3.147 $\AA$ ), respectively [57]. The calculated lattice 
parameters for the FCC matrix of $\mathrm{Fe}_{40} \mathrm{Cr}_{15} \mathrm{Co}_{15} \mathrm{Mn}_{10} \mathrm{Ni}_{20}, \mathrm{Fe}_{40} \mathrm{Cr}_{15} \mathrm{Co}_{10} \mathrm{Mn}_{4} \mathrm{Ni}_{20} \mathrm{Al}_{11}$, and $\mathrm{Fe}_{40} \mathrm{Cr}_{15} \mathrm{Co}_{10} \mathrm{Mn}_{5} \mathrm{Ni}_{20} \mathrm{Mo}_{10}$ are $3.62980 \AA$, $3.66169 \AA$, and $3.58698 \AA$, which are slightly different from the measured lattice parameter and with the relative errors of $1.272 \%, 1.637 \%$, $-0.490 \%$, respectively. The relative errors between calculated values and the experimental data are caused by the approximate empirical characteristic of Vegard's law which ignores the change of atomic radius during solid solution formation, the atomic outer electron density, and cohesive energy of the chemical compositions [56,58-63].

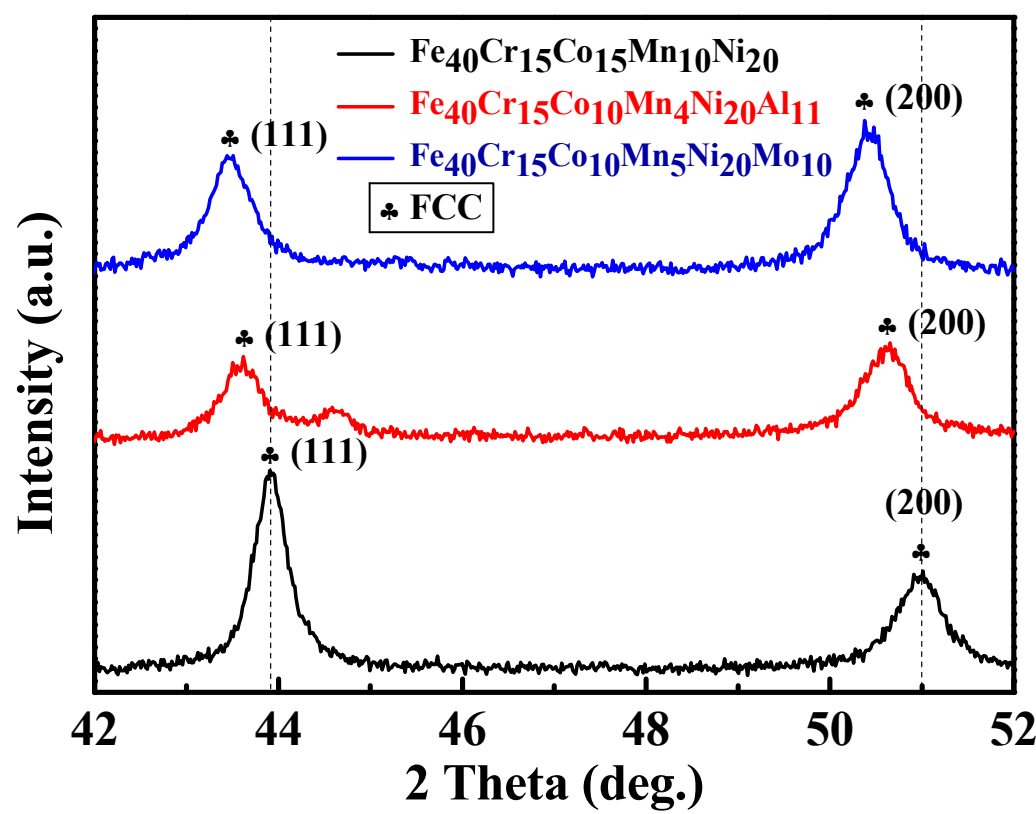

Figure 2. The (111) FCC and (200) FCC diffraction peak shift of the three high-entropy alloys.

Table 2. EDS results of $\mathrm{Fe}_{40} \mathrm{Cr}_{15} \mathrm{Co}_{15} \mathrm{Mn}_{10} \mathrm{Ni}_{20}$ alloy in different regions.

\begin{tabular}{cccccc}
\hline \multirow{2}{*}{ Region } & \multicolumn{5}{c}{ Chemical Compositions (at.\%) } \\
\cline { 2 - 6 } & Fe & Cr & Co & Mn & Ni \\
\hline 3 & 32.4 & 16.0 & 13.8 & 15.2 & 22.6 \\
A & 37.7 & 16.6 & 15.0 & 10.4 & 20.3 \\
\hline
\end{tabular}

Table 3. EDS results of $\mathrm{Fe}_{40} \mathrm{Cr}_{15} \mathrm{Co}_{10} \mathrm{Mn}_{4} \mathrm{Ni}_{20} \mathrm{Al}_{11}$ alloy in different regions.

\begin{tabular}{ccccccccc}
\hline \multirow{2}{*}{ Region } & \multirow{2}{*}{ Phase } & \multicolumn{5}{c}{ Chemical Compositions (at.\%) } \\
\cline { 3 - 8 } & & Fe & Cr & Co & Mn & Ni & Al \\
\hline B & FCC & 39.1 & 16.8 & 10.3 & 4.3 & 19.7 & 9.8 \\
4 & BCC & 29.0 & 15.2 & 8.9 & 5.0 & 23.4 & 18.5 & 22.5 \\
5 & BCC & 29.0 & 14.9 & 8.8 & 4.6 & 20.2 & 22.1 & 12.9 \\
\hline
\end{tabular}

Table 4. EDS results of the $\mathrm{Fe}_{40} \mathrm{Cr}_{15} \mathrm{Co}_{10} \mathrm{Mn}_{5} \mathrm{Ni}_{20} \mathrm{Mo}_{10}$ alloy in different regions.

\begin{tabular}{|c|c|c|c|c|c|c|c|}
\hline \multirow{2}{*}{ Region } & \multirow{2}{*}{ Phase } & \multicolumn{6}{|c|}{ Chemical Compositions (at.\%) } \\
\hline & & $\mathrm{Fe}$ & $\mathrm{Cr}$ & Co & Mn & $\mathbf{N i}$ & Mo \\
\hline $\mathrm{D}$ & FCC & 42.8 & 15.2 & 10.4 & 4.5 & 20.1 & 7.0 \\
\hline $\mathrm{E}$ & $\mu$ & 30.5 & 19.5 & 8.1 & 4.0 & 10.2 & 27.7 \\
\hline $\mathrm{F}$ & FCC & 40.3 & 15.7 & 9.8 & 4.9 & 20.2 & 9.1 \\
\hline $\mathrm{G}$ & $\mu$ & 31.0 & 19.4 & 7.7 & 3.7 & 10.2 & 28.0 \\
\hline The overall surface of the alloy & / & 41.3 & 15.4 & 10.0 & 4.6 & 19.9 & 8.8 \\
\hline
\end{tabular}


It is interesting that the measured lattice parameter of the FCC matrix for $\mathrm{Fe}_{40} \mathrm{Cr}_{15} \mathrm{Co}_{10}$ $\mathrm{Mn}_{4} \mathrm{Ni}_{20} \mathrm{Al}_{11}\left(3.60273 \AA\right.$ ) is slightly smaller than the $\mathrm{Fe}_{40} \mathrm{Cr}_{15} \mathrm{Co}_{10} \mathrm{Mn}_{5} \mathrm{Ni}_{20} \mathrm{Mo}_{10}(3.60465 \AA)$ alloy, even though the atomic radius of $\mathrm{Al}(1.43 \AA)$ is larger than Mo (1.39 $\AA$ ). This might be ascribed to the formation of the BCC phase (rich in Al according to the EDS analysis below (Table 3)) in the FCC matrix of the $\mathrm{Fe}_{40} \mathrm{Cr}_{15} \mathrm{Co}_{10} \mathrm{Mn}_{4} \mathrm{Ni}_{20} \mathrm{Al}_{11}$ alloy, which reduces the lattice expansion extent. This phenomenon can be understood via Vegard's law [56]. Assuming the $\mathrm{Fe}_{40} \mathrm{Cr}_{15} \mathrm{Co}_{10} \mathrm{Mn}_{4} \mathrm{Ni}_{20} \mathrm{Al}_{11}$ alloy contains single FCC solid solution and the molar percentage for each composition is obtained by EDS result from the overall surface of the alloy (see Table 3), the calculated lattice parameter for the assumed FCC solid solution is $3.67231 \AA$. This value is much larger than the calculated lattice parameter for the actual FCC matrix of $\mathrm{Fe}_{40} \mathrm{Cr}_{15} \mathrm{Co}_{10} \mathrm{Mn}_{4} \mathrm{Ni}_{20} \mathrm{Al}_{11}$ (3.66169 $\mathrm{A}$ ), suggesting the lattice expansion extent could be reduced by the formation of the BCC phase. Similar trends are reported elsewhere $[29,30]$.

\subsection{Metallographic Morphology}

To understand the phase variations caused by the addition of Al or Mo, metallographic analysis of the three high-entropy alloys was performed, as shown in Figure 3. The metallographic structure of the $\mathrm{Fe}_{40} \mathrm{Cr}_{15} \mathrm{Co}_{15} \mathrm{Mn}_{10} \mathrm{Ni}_{20}$ alloy is shown in Figure 3a. It has a single phase with a dendritic structure, which is consistent with the XRD analysis. With the addition of the $\mathrm{Al}$, the $\mathrm{Fe}_{40} \mathrm{Cr}_{15} \mathrm{Co}_{10} \mathrm{Mn}_{4} \mathrm{Ni}_{20} \mathrm{Al}_{11}$ alloy consists of a brighter matrix and darker secondary phases located along grain boundaries (Figure $3 \mathrm{~b}$ ). These dark secondary phases are associated with the BCC-structured phase, as suggested by the XRD analysis. After the addition of $\mathrm{Mo}$, the $\mathrm{Fe}_{40} \mathrm{Cr}_{15} \mathrm{Co}_{10} \mathrm{Mn}_{5} \mathrm{Ni}_{20} \mathrm{Mo}_{10}$ alloy exhibits distinguished features, as shown in Figure 3c. Long strip and short rod-shaped intermetallic compounds not only distribute along the grain boundaries but also disperse within the crystal grains. These secondary phases should be the intermetallic compounds according to the XRD analysis.

\subsection{Scanning Electron Microscopy}

SEM observation revealed that $\mathrm{Fe}_{40} \mathrm{Cr}_{15} \mathrm{Co}_{15} \mathrm{Mn}_{10} \mathrm{Ni}_{20}$ alloy is a single-phase matrix accompanied by a certain number of spherical structures, as shown in Figure 4. EDS results (Table 2) indicate that the composition of the FCC-structured matrix (region A) is similar to the overall content of the cast ingot, whereas a higher content of $\mathrm{Mn}$ and $\mathrm{Ni}$ are detected near the grain boundary (region 3). This is because the melting temperatures of Mn and Ni elements are relatively low, which leads to the segregation during the solidification process [64]. The bright round features (e.g., regions 1 and 2) are cavities which could be formed during the process of alloy preparation. These findings agree well with the research results of Ye et al. [65].

For the $\mathrm{Fe}_{40} \mathrm{Cr}_{15} \mathrm{Co}_{10} \mathrm{Mn}_{4} \mathrm{Ni}_{20} \mathrm{Al}_{11}$ alloy, brighter secondary phases are visible along grain boundaries, as shown in Figure 5a,b. Among them, long strips and rectangular granular structures are observed, as shown in the positions of points 4 and 5 in Figure $5 b$, respectively, which contain similar compositions and are all rich in $\mathrm{Al}$ and $\mathrm{Ni}$ as indicated by the EDS results (Table 3). The matrix appears dark in contrast (region B), which contains a lower amount of $\mathrm{Al}$ and $\mathrm{Ni}$ but more $\mathrm{Fe}$ as compared to the brighter secondary phases. According to XRD analysis and metallographic observation, the brighter secondary phases are BCC-structured secondary phases while the darker matrix is the FCC-structured phase [66]. The morphology of the BCC-structured secondary phases is also observed by a backscattered electron image as shown in Figure 5c. It exhibits a fine-scale structure containing alternating bright and dark interconnected phases, which has been reported to be formed due to the large negative mixing enthalpy of $\mathrm{Al}$ and $\mathrm{Ni}$ facilitating the formation of the Al-Ni rich phases during solidification $[48,67,68]$. 

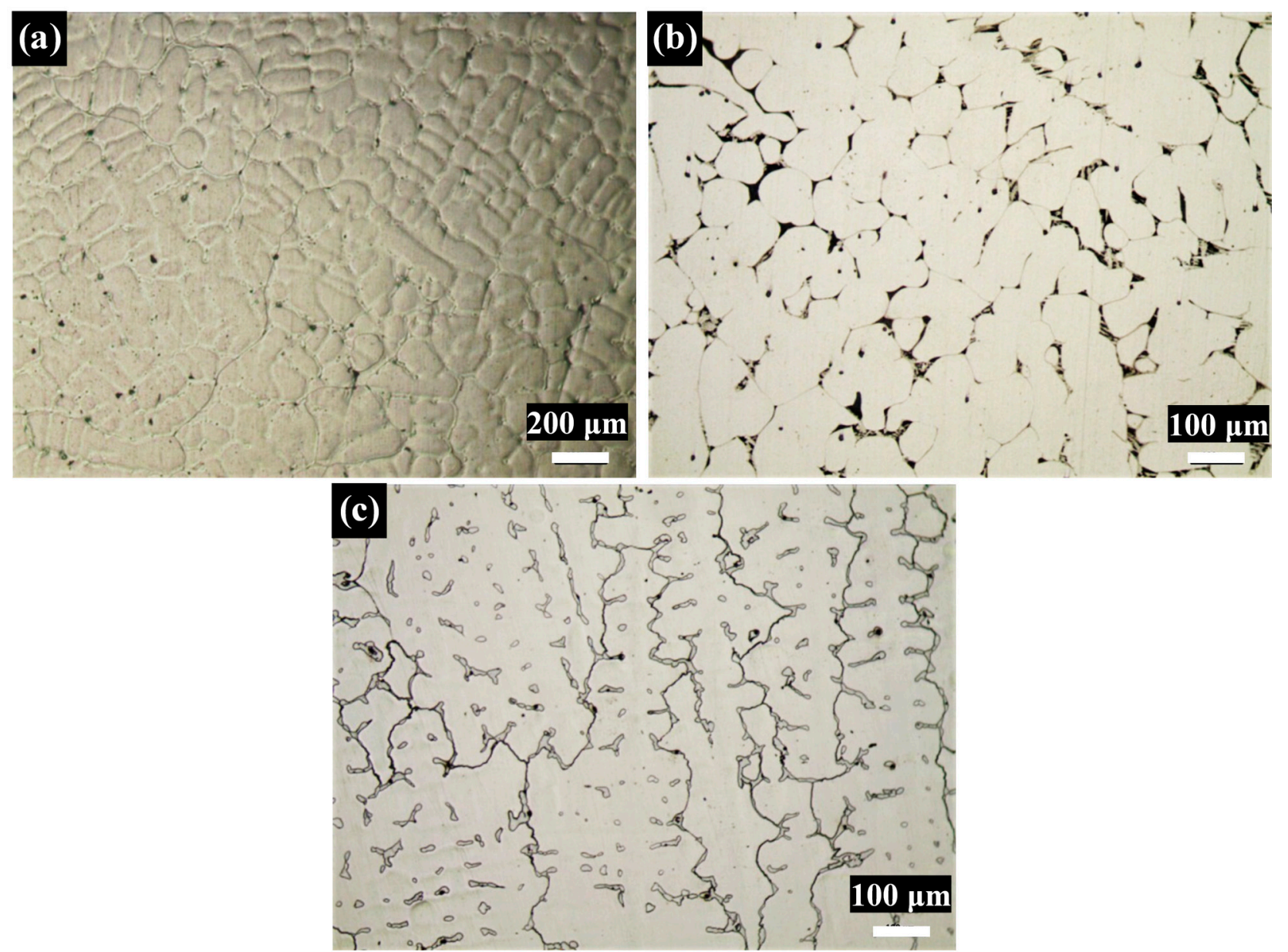

Figure 3. The Metallographic structure of high-entropy alloys. (a) $\mathrm{Fe}_{40} \mathrm{Cr}_{15} \mathrm{Co}_{15} \mathrm{Mn}_{10} \mathrm{Ni}_{20}$; (b) $\mathrm{Fe}_{40} \mathrm{Cr}_{15} \mathrm{Co}_{10} \mathrm{Mn}_{4} \mathrm{Ni}_{20} \mathrm{Al}_{11}$; and (c) $\mathrm{Fe}_{40} \mathrm{Cr}_{15} \mathrm{Co}_{10} \mathrm{Mn}_{5} \mathrm{Ni}_{20} \mathrm{Mo}_{10}$.

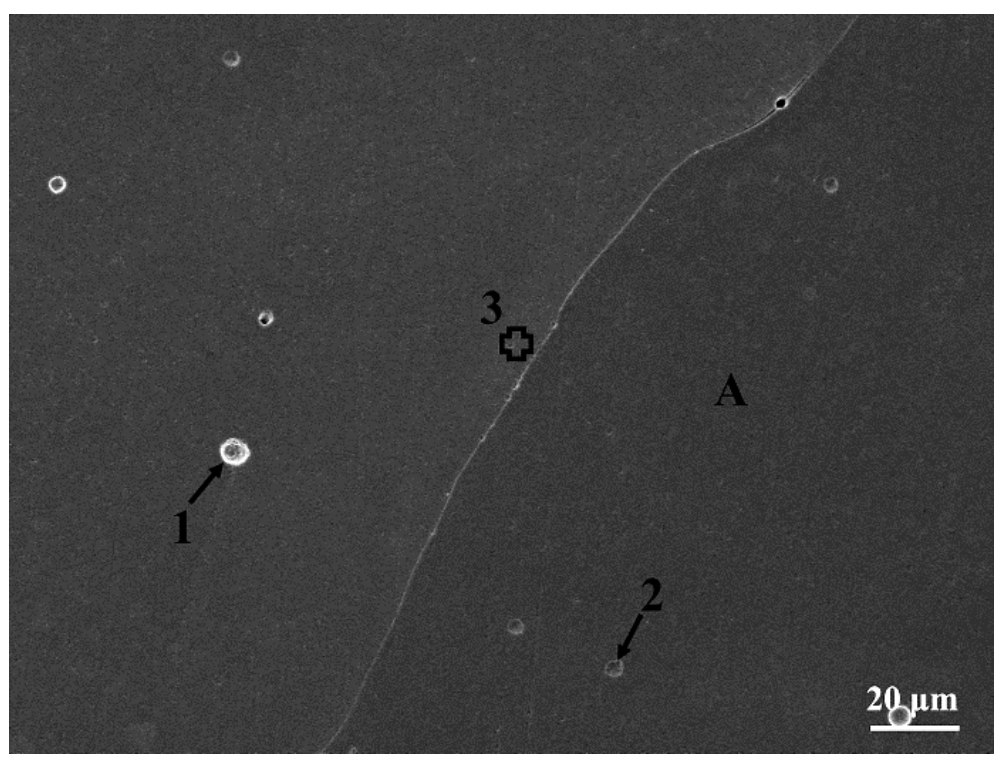

Figure 4. Microstructure of the $\mathrm{Fe}_{40} \mathrm{Cr}_{15} \mathrm{Co}_{15} \mathrm{Mn}_{10} \mathrm{Ni}_{20}$ alloy.

For the $\mathrm{Fe}_{40} \mathrm{Cr}_{15} \mathrm{Co}_{10} \mathrm{Mn}_{5} \mathrm{Ni}_{20} \mathrm{Mo}_{10}$ alloy with 10 at.\% Mo addition, a large number of secondary phases are present predominantly along the grain boundaries and marginally within the grains, as shown in Figure 6. The EDS results of different regions in the alloy 
are shown in Table 4. It reveals that the FCC-structured matrix (region D) shows similar composition as that of the cast ingot, while the brighter region (region F) adjacent to the grain boundaries contains a higher amount of Mo as compared to the matrix (region D), which should be attributed to the Mo segregation during the solidification process [30]. The secondary phases (regions $\mathrm{E}$ and $\mathrm{G}$ ) within grains and along grain boundaries are found to be enriched in Mo and Cr, while the content of the Mo is approximately 4 times higher than the FCC matrix, which is reported to be typical (Mo, Cr)-rich intermetallic compound $(\mu)$ with Mo content greater than $\mathrm{Cr}[69]$.
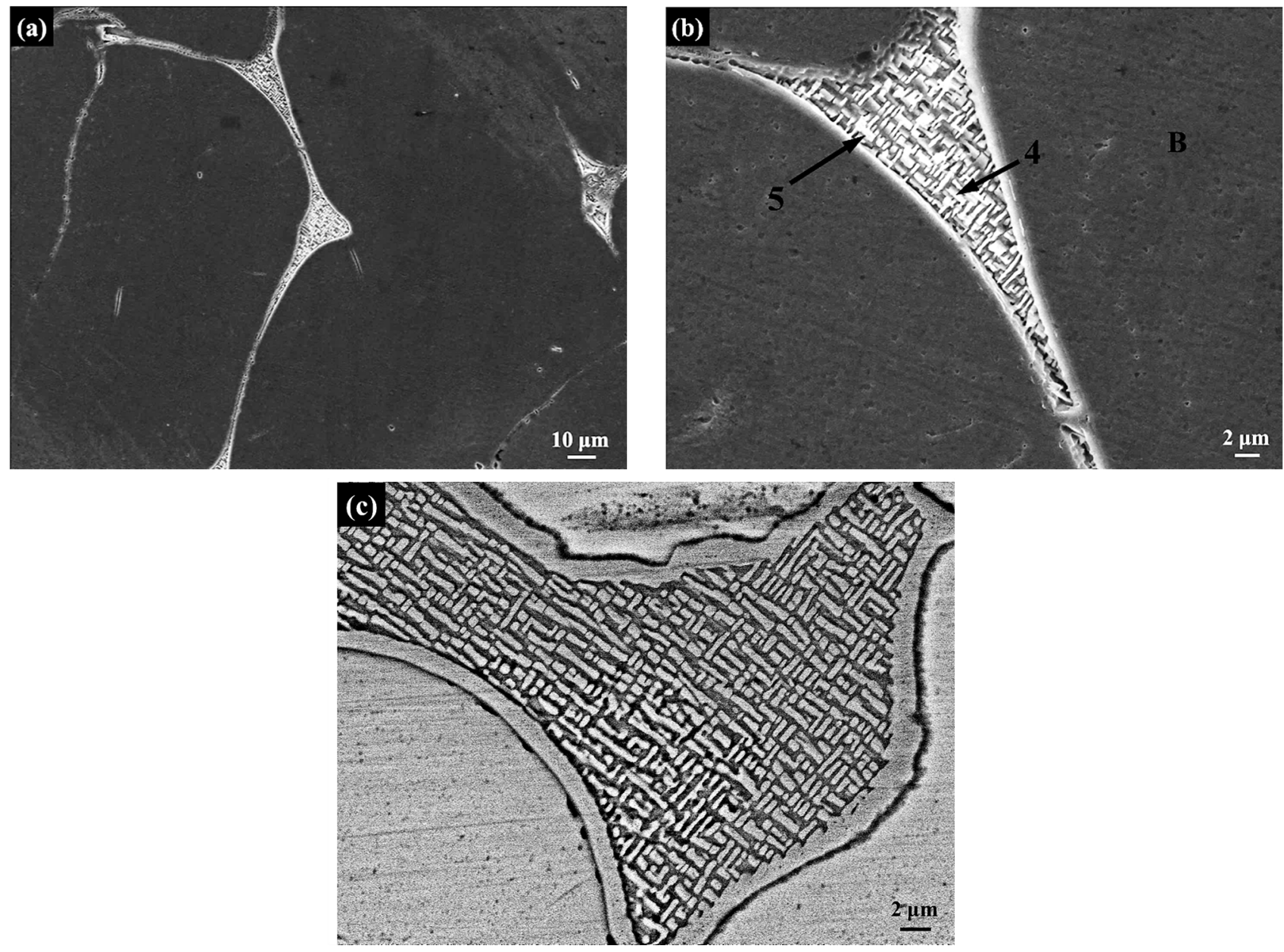

Figure 5. Microstructure of the $\mathrm{Fe}_{40} \mathrm{Cr}_{15} \mathrm{Co}_{10} \mathrm{Mn}_{4} \mathrm{Ni}_{20} \mathrm{Al}_{11}$ alloy. (a) $500 \times$; (b,c) $2000 \times$. Note (a,b) are secondary electron images, whereas $(c)$ is the backscattered electron image.

In addition, a trace of white phases with their morphology completely different from that of the intermetallic compound $(\mu)$ are occasionally found at the grain boundaries, as shown in Figure 7. EDS results, as listed in Table 5, reveal that these white phases are slightly enriched in $\mathrm{Cr}$ and $\mathrm{Mo}$, and the content of $\mathrm{Cr}$ is greater than that of Mo. It suggests the white phases are a $(\mathrm{Cr}, \mathrm{Mo})$-rich $\sigma$ intermetallic compound, which is consistent with previous results [69]. Note that the ( $\mathrm{Cr}, \mathrm{Mo})$-rich $\sigma$ intermetallic compound is not identified from the XRD analysis, because its content is lower than the detection limit of the XRD. It has been reported that the $\sigma$ phase in high-entropy alloys tends to transform into $\mu$ phase to release the larger lattice strain caused by Mo $[30,50]$. The $\sigma$ phase could be completely converted to $\mu$ phase when the content of Mo is high [6]. Therefore, the trace of $\sigma$ phase found in the $\mathrm{Fe}_{40} \mathrm{Cr}_{15} \mathrm{Co}_{10} \mathrm{Mn}_{5} \mathrm{Ni}_{20} \mathrm{Mo}_{10}$ alloy should be the residual phases as a result of the phase transformation. 

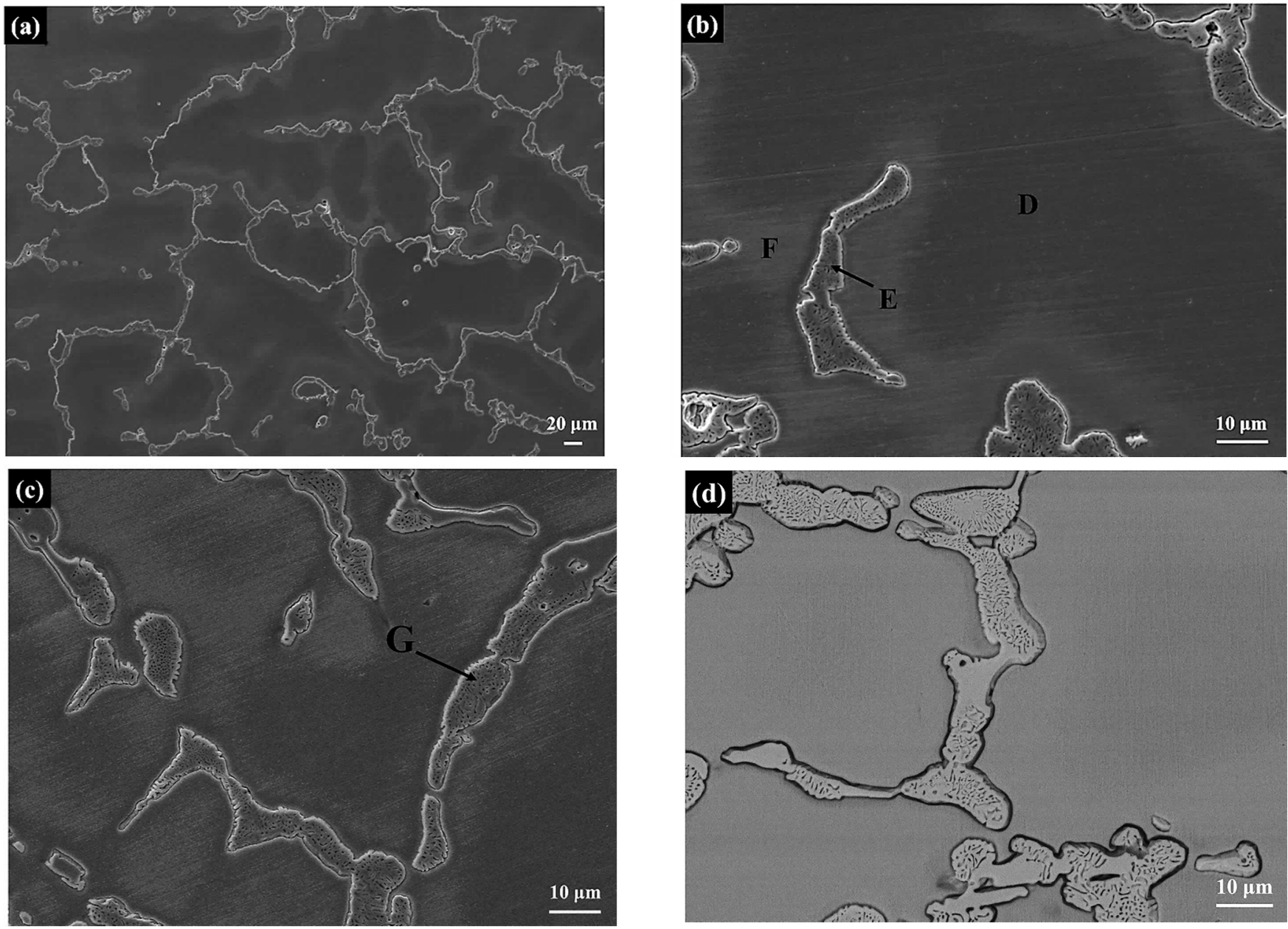

Figure 6. Microstructure of the $\mathrm{Fe}_{40} \mathrm{Cr}_{15} \mathrm{Co}_{10} \mathrm{Mn}_{5} \mathrm{Ni}_{20} \mathrm{Mo}_{10}$ alloy. (a) Low-magnification image, $200 \times$; $(\mathbf{b}, \mathbf{c})$ High-magnification images showing the secondary phases in the interior of the grains and at the grain boundaries, $1000 \times$. Note that $(\mathbf{a}-\mathbf{c})$ are secondary electron images, whereas $(\mathbf{d})$ is the backscattered electron image.
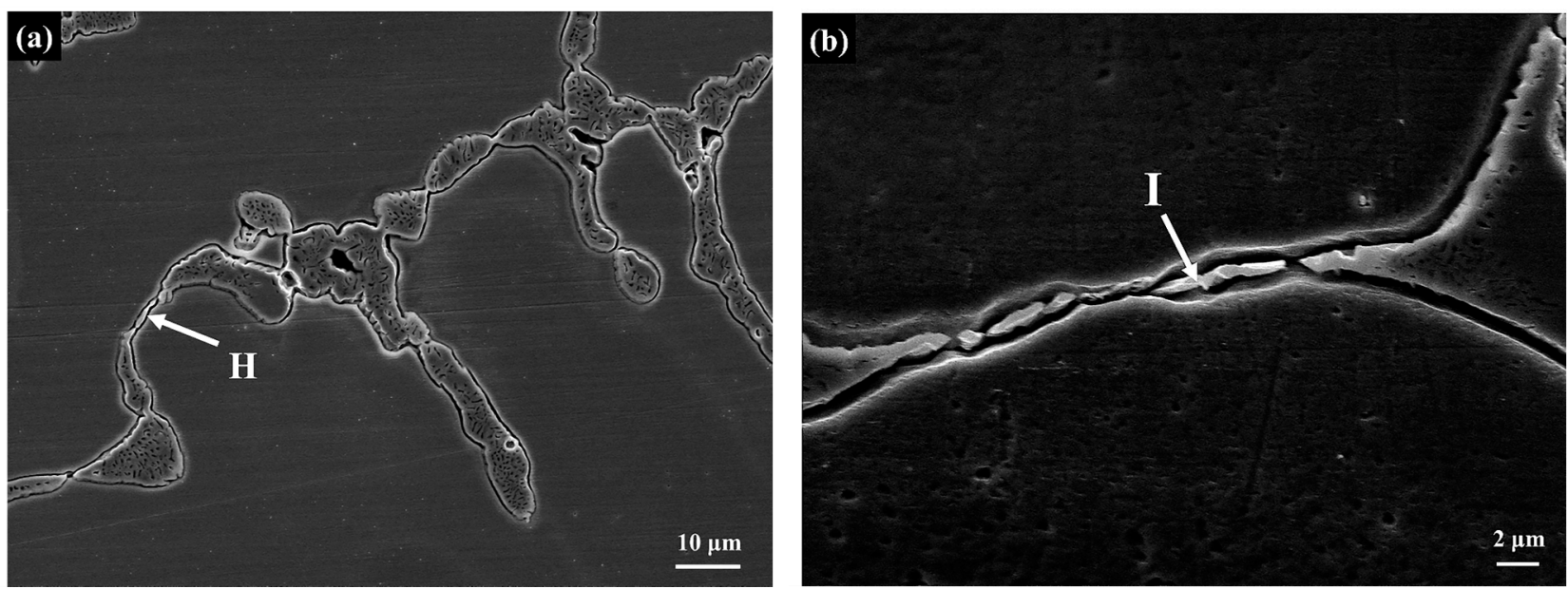

Figure 7. Fine intermetallic compounds in the $\mathrm{Fe}_{40} \mathrm{Cr}_{15} \mathrm{Co}_{10} \mathrm{Mn}_{5} \mathrm{Ni}_{20} \mathrm{Mo}_{10}$ alloy: (a) $1000 \times$; (b) $3000 \times$. The brighter phases (marked by $\mathrm{H}$ and I) at the grain boundaries are the intermetallic compound $\sigma$. Note $(\mathbf{a}, \mathbf{b})$ are secondary electron images. 
Table 5. EDS results of fine intermetallic compounds in the $\mathrm{Fe}_{40} \mathrm{Cr}_{15} \mathrm{Co}_{10} \mathrm{Mn}_{5} \mathrm{Ni}_{20} \mathrm{Mo}_{10}$ alloy.

\begin{tabular}{cccccccc}
\hline \multirow{2}{*}{ Region } & \multirow{2}{*}{ Phase } & \multicolumn{7}{c}{ Chemical Compositions (at.\%) } \\
\cline { 2 - 8 } & & Fe & Cr & Co & Mn & Ni & Mo \\
\hline H & $\sigma$ & 38.4 & 17.1 & 9.6 & 5.4 & 18.2 & 11.3 \\
\hline I & $\sigma$ & 37.7 & 16.2 & 9.5 & 5.8 & 19.0 & 11.8 \\
\hline
\end{tabular}

\subsection{Vickers Hardness}

The Vickers hardness of the three high-entropy alloys is shown in Figure 8. The results reveal that the single-phase $\mathrm{Fe}_{40} \mathrm{Cr}_{15} \mathrm{Co}_{15} \mathrm{Mn}_{10} \mathrm{Ni}_{20}$ alloy possesses the lowest Vickers hardness of $148.2 \pm 5.9 \mathrm{HV}$. After the addition of $\mathrm{Al}$ or Mo, the $\mathrm{Fe}_{40} \mathrm{Cr}_{15} \mathrm{Co}_{10} \mathrm{Mn}_{4} \mathrm{Ni}_{20} \mathrm{Al}_{11}$ and $\mathrm{Fe}_{40} \mathrm{Cr}_{15} \mathrm{Co}_{10} \mathrm{Mn}_{5} \mathrm{Ni}_{20} \mathrm{Mo}_{10}$ alloys exhibit the Vickers hardness of $165.6 \pm 24.2$ and $208.1 \pm 20.5 \mathrm{HV}$, respectively. It suggests the addition of the $\mathrm{Al}$ or Mo may have caused second phase strengthening and solid-solution strengthening, which improves the Vickers hardness of the high-entropy alloys. The increase in the Vickers hardness as a result of $\mathrm{Al}$ and Mo addition is, respectively, 17.45 and $59.92 \mathrm{HV}$, suggesting the strengthening effect is more pronounced when Mo is employed as compared to Al.

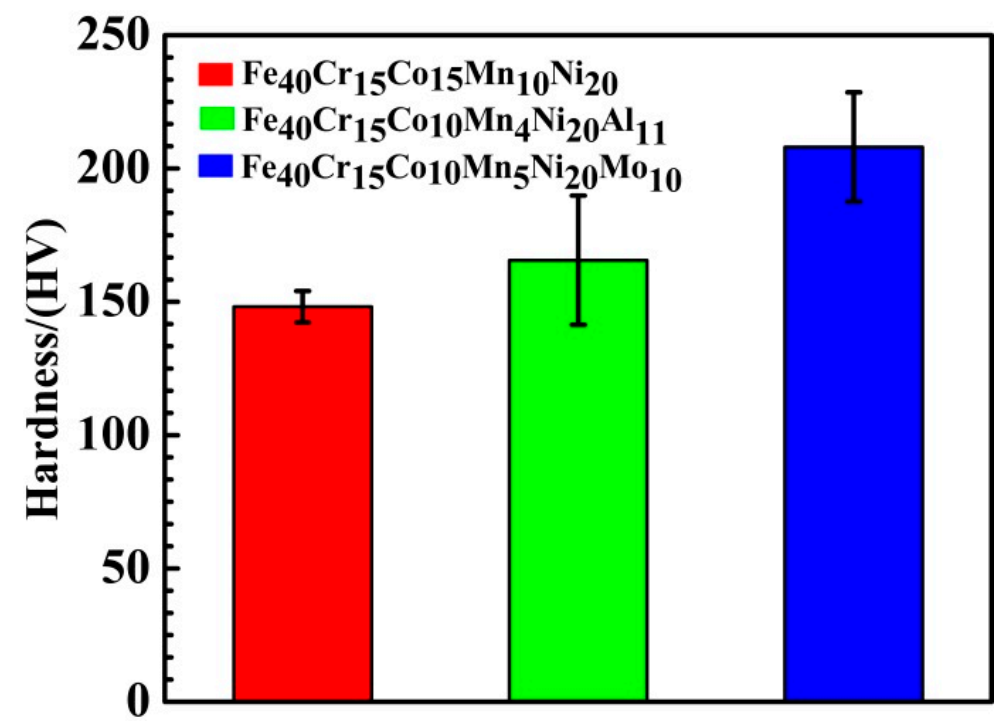

Figure 8. Vickers microhardness of the three high-entropy alloys.

\subsection{Tensile Testing}

\subsubsection{Tensile Strength and Plasticity}

The stress-strain curves of the three high-entropy alloys are shown in Figure 9. It reveals that the single-phase $\mathrm{Fe}_{40} \mathrm{Cr}_{15} \mathrm{Co}_{15} \mathrm{Mn}_{10} \mathrm{Ni}_{20}$ alloy has a yield strength $\left(\sigma_{0.2}\right)$ of $158 \pm 4 \mathrm{MPa}$ and ultimate tensile strength (UTS) of $420 \pm 20 \mathrm{MPa}$. For the Al-strengthening FCC/BCC dual-structured $\mathrm{Fe}_{40} \mathrm{Cr}_{15} \mathrm{Co}_{10} \mathrm{Mn}_{4} \mathrm{Ni}_{20} \mathrm{Al}_{11}$ alloy, the $\sigma_{0.2}$ and UTS are increased to $218 \pm 7$ and $507 \pm 16 \mathrm{MPa}$ respectively. However, the Mo-containing $\mathrm{Fe}_{40} \mathrm{Cr}_{15} \mathrm{Co}_{10} \mathrm{Mn}_{5} \mathrm{Ni}_{20}$ $\mathrm{Mo}_{10}$ alloy exhibits a UTS of $346 \pm 15 \mathrm{MPa}$, even though it has a higher $\sigma_{0.2}$ of $246 \pm 15 \mathrm{MPa}$. Note that many researchers focused on the compressive properties of the $\mathrm{FeCrCoMnNiMo}$ system high-entropy alloys rather than the tensile properties due to the existing brittle intermetallic compounds $[30,50,70,71]$. In this investigation, we report the tensile properties as they are of great significance for practical engineering applications.

After the test, the elongation at fracture (A) and reduction of area (Z) were measured by using the fractured samples and summarized in Figure 10a,b. The single-phase FCC-structured $\mathrm{Fe}_{40} \mathrm{Cr}_{15} \mathrm{Co}_{15} \mathrm{Mn}_{10} \mathrm{Ni}_{20}$ alloy shows excellent ductility with the elongation at fracture and reduction of area of $53.4 \pm 3.4 \%$ (A) and $40.5 \pm 0.2 \%(\mathrm{Z})$, respectively. For the dual-structured $\mathrm{Fe}_{40} \mathrm{Cr}_{15} \mathrm{Co}_{10} \mathrm{Mn}_{4} \mathrm{Ni}_{20} \mathrm{Al}_{11}$ alloy, the elongation at fracture and 
reduction of area are $42.3 \pm 0.4 \%$ (A) and $26.4 \pm 1.6 \%(\mathrm{Z})$, respectively, which is slightly lower than that of the single-phase $\mathrm{Fe}_{40} \mathrm{Cr}_{15} \mathrm{Co}_{15} \mathrm{Mn}_{10} \mathrm{Ni}_{20}$ alloy. With the addition of Mo, the ductility of the $\mathrm{Fe}_{40} \mathrm{Cr}_{15} \mathrm{Co}_{10} \mathrm{Mn}_{5} \mathrm{Ni}_{20} \mathrm{Mo}_{10}$ alloy significantly deteriorates. Its elongation at fracture and reduction of area are only $7.0 \pm 0.6 \%(\mathrm{~A})$ and $6.0 \pm 0.8 \%(\mathrm{Z})$, respectively, which is much lower than the other two high-entropy alloys. In addition, necking was observed during the tensile tests, especially for the $\mathrm{Fe}_{40} \mathrm{Cr}_{15} \mathrm{Co}_{15} \mathrm{Mn}_{10} \mathrm{Ni}_{20}$ alloy because of its superior ductility (Figure 11c). The necking is less pronounced for the $\mathrm{Fe}_{40} \mathrm{Cr}_{15} \mathrm{Co}_{10} \mathrm{Mn}_{4} \mathrm{Ni}_{20} \mathrm{Al}_{11}$ alloy (Figure 11d). However, the necking phenomenon can hardly be seen for the $\mathrm{Fe}_{40} \mathrm{Cr}_{15} \mathrm{Co}_{10} \mathrm{Mn}_{5} \mathrm{Ni}_{20} \mathrm{Mo}_{10}$ alloy due to the deterioration in the ductility (Figure 12d). These findings are consistent with the results of the reduction of area (Z) of the three high-entropy alloys. It is speculated that the formation of a large number of intermetallic compounds should be responsible for premature fracture and deteriorated tensile strength.

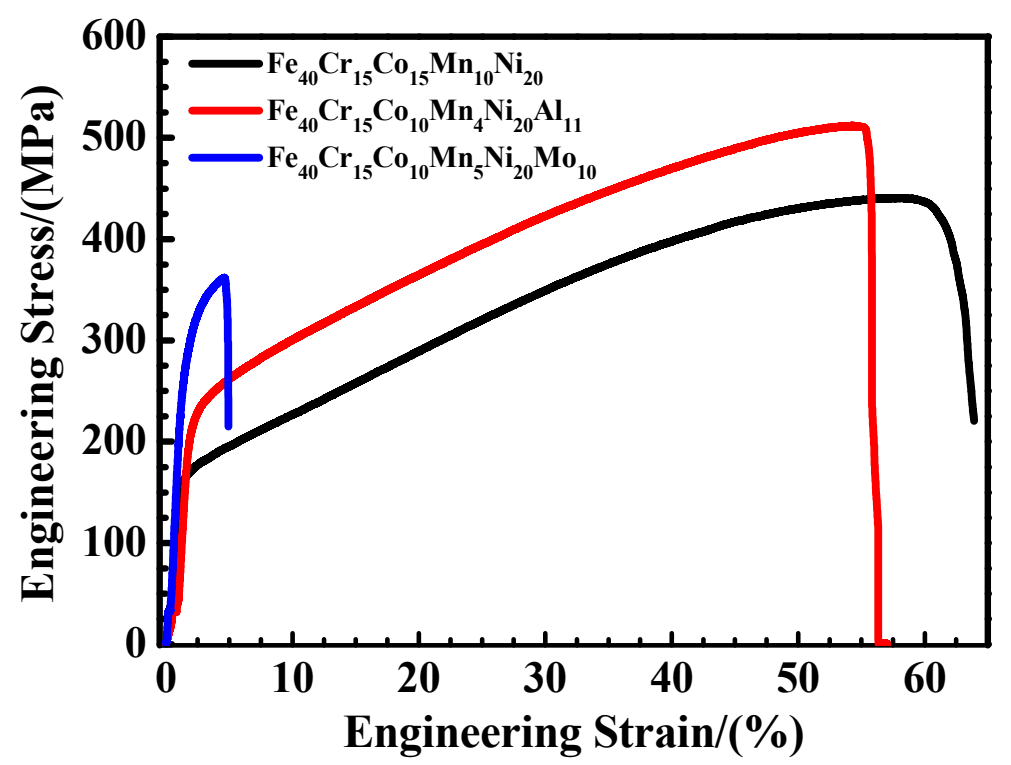

Figure 9. The stress-strain curves of the three high-entropy alloys.
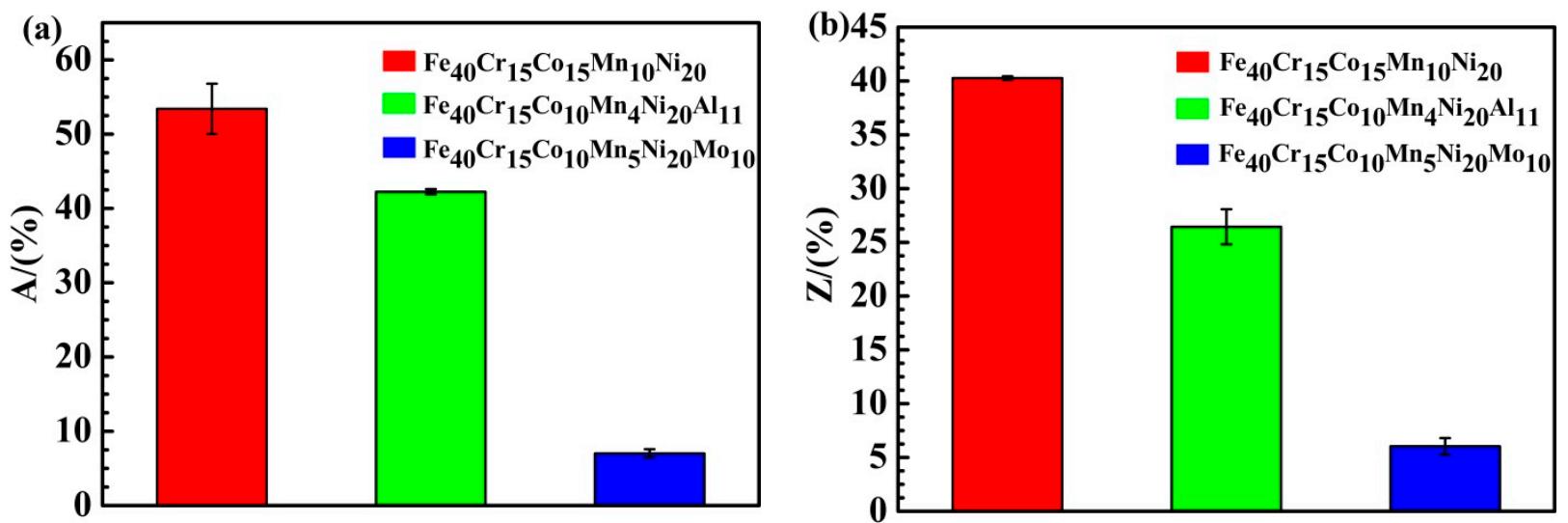

Figure 10. Elongation at fracture $(\mathrm{A})$ and reduction of area $(\mathrm{Z})$ of the three high-entropy alloys: (a) elongation at fracture; (b) reduction of area.

\subsubsection{Fractography}

Figure 11 shows the fracture surfaces of the $\mathrm{Fe}_{40} \mathrm{Cr}_{15} \mathrm{Co}_{15} \mathrm{Mn}_{10} \mathrm{Ni}_{20}$ and $\mathrm{Fe}_{40} \mathrm{Cr}_{15} \mathrm{Co}_{10} \mathrm{Mn}_{4}$ $\mathrm{Ni}_{20} \mathrm{Al}_{11}$ alloys. For the former, a large number of deep ductile dimples accompanied by many tearing edges around the dimples are observed on the fracture surface, which is a typical characteristic of ductile fracture (Figure 11a). For the latter, slightly less and shallower ductile dimples 
and their surrounding tearing edges can be identified even though the fracture mechanism remains the same comparing to the former (Figure 11b). Moreover, a few granular phases in and around the ductile dimples appear on the fracture surface of the $\mathrm{Fe}_{40} \mathrm{Cr}_{15} \mathrm{Co}_{10} \mathrm{Mn}_{4} \mathrm{Ni}_{20} \mathrm{Al}_{11}$ alloys, which are determined to be Al-rich granular phases (Table 6).
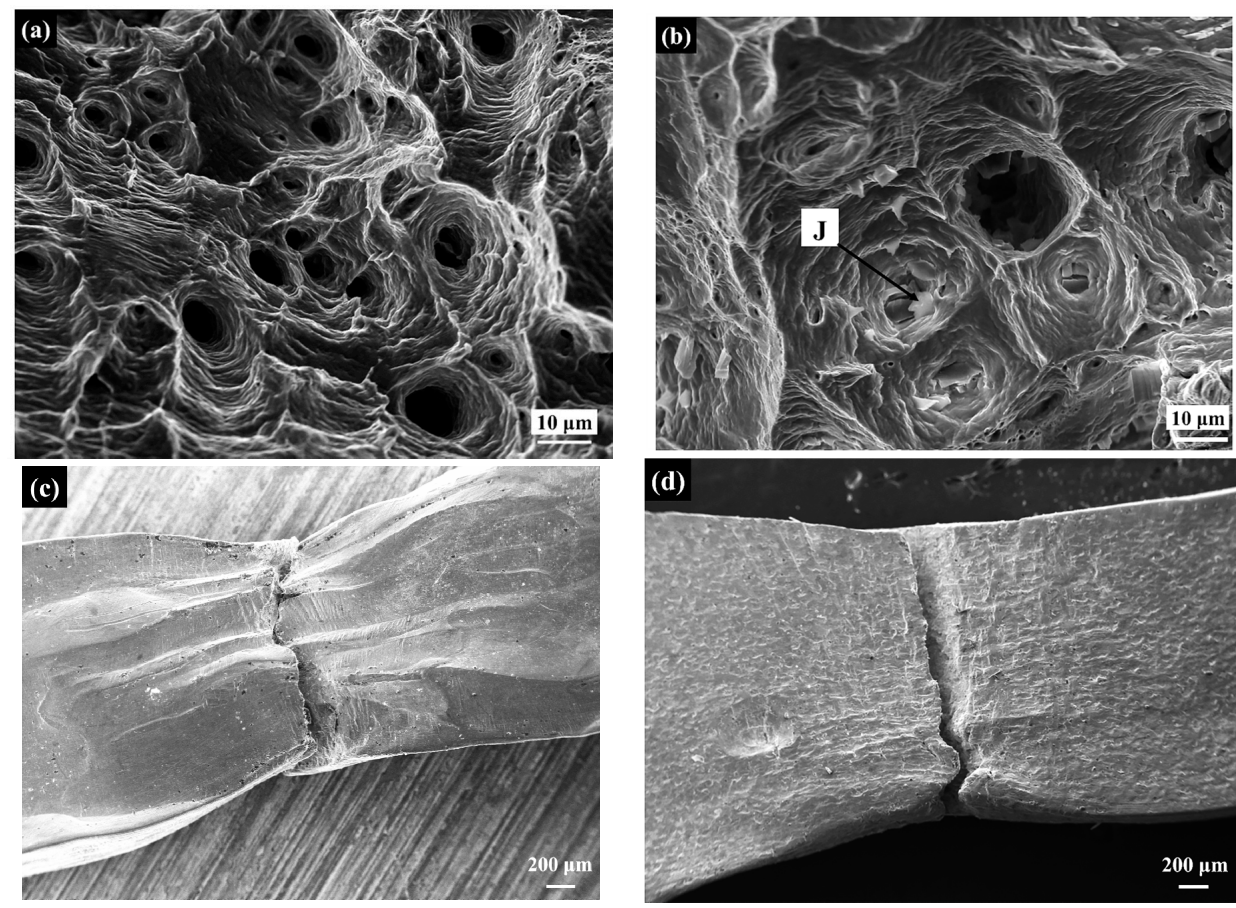

Figure 11. The fracture surface of the high-entropy alloys: (a) $\mathrm{Fe}_{40} \mathrm{Cr}_{15} \mathrm{Co}_{15} \mathrm{Mn}_{10} \mathrm{Ni}_{20}$; (b) $\mathrm{Fe}_{40} \mathrm{Cr}_{15} \mathrm{Co}_{10} \mathrm{Mn}_{4} \mathrm{Ni}_{20} \mathrm{Al}_{11}$; images (c,d) are the macro morphology of the $\mathrm{Fe}_{40} \mathrm{Cr}_{15} \mathrm{Co}_{15} \mathrm{Mn}_{10} \mathrm{Ni}_{20}$ and $\mathrm{Fe}_{40} \mathrm{Cr}_{15} \mathrm{Co}_{10} \mathrm{Mn}_{4} \mathrm{Ni}_{20} \mathrm{Al}_{11}$ tensile specimens after fracture, respectively.

For the $\mathrm{Fe}_{40} \mathrm{Cr}_{15} \mathrm{Co}_{10} \mathrm{Mn}_{5} \mathrm{Ni}_{20} \mathrm{Mo}_{10}$ alloy, its UTS and elongation are significantly degraded, even though the hardness and $\sigma_{0.2}$ are improved by the formation of $\mu$ and $\sigma$ intermetallic compounds resulting from the addition of Mo. Figure 12 shows the fracture surface of the $\mathrm{Fe}_{40} \mathrm{Cr}_{15} \mathrm{Co}_{10} \mathrm{Mn}_{5} \mathrm{Ni}_{20} \mathrm{Mo}_{10}$ alloy. A river-like pattern without apparent ductile dimples is observed on the fracture surface, which is a typical feature of brittle fracture, as shown in Figure 12a. Moreover, numerous fine particles distribute on the fracture surface, as shown in the high-magnified image (Figure 12b), which are the intermetallic compounds $\mu$ and $\sigma$ according to the EDS results (Table 7). Further, multiple cracks appear on the fracture surface (Figure 12c).

Table 6. EDS results of granular phases on the fracture surface of the $\mathrm{Fe}_{40} \mathrm{Cr}_{15} \mathrm{Co}_{10} \mathrm{Mn}_{4} \mathrm{Ni}_{20} \mathrm{Al}_{11}$ alloy.

\begin{tabular}{ccccccc}
\hline \multirow{2}{*}{ Region } & \multicolumn{7}{c}{ Chemical Compositions (at.\%) } \\
\cline { 2 - 7 } & Fe & Cr & Co & Mn & Ni & Al \\
\hline J & 22.2 & 11.4 & 2.1 & 3.8 & 5.5 & 55.0 \\
\hline
\end{tabular}

Table 7. EDS results of the fine particles on fracture surface of the $\mathrm{Fe}_{40} \mathrm{Cr}_{15} \mathrm{Co}_{10} \mathrm{Mn}_{5} \mathrm{Ni}_{20} \mathrm{Mo}_{10}$ alloy.

\begin{tabular}{ccccccc}
\hline \multirow{2}{*}{ Region } & \multicolumn{7}{c}{ Chemical Compositions (at.\%) } \\
\cline { 2 - 7 } & Fe & Cr & Co & Mn & Ni & Mo \\
\hline$\mu$ & 31.4 & 19.6 & 9.1 & 3.4 & 12.4 & 24.1 \\
$\sigma$ & 36.8 & 17.0 & 9.1 & 5.8 & 19.5 & 11.8 \\
\hline
\end{tabular}



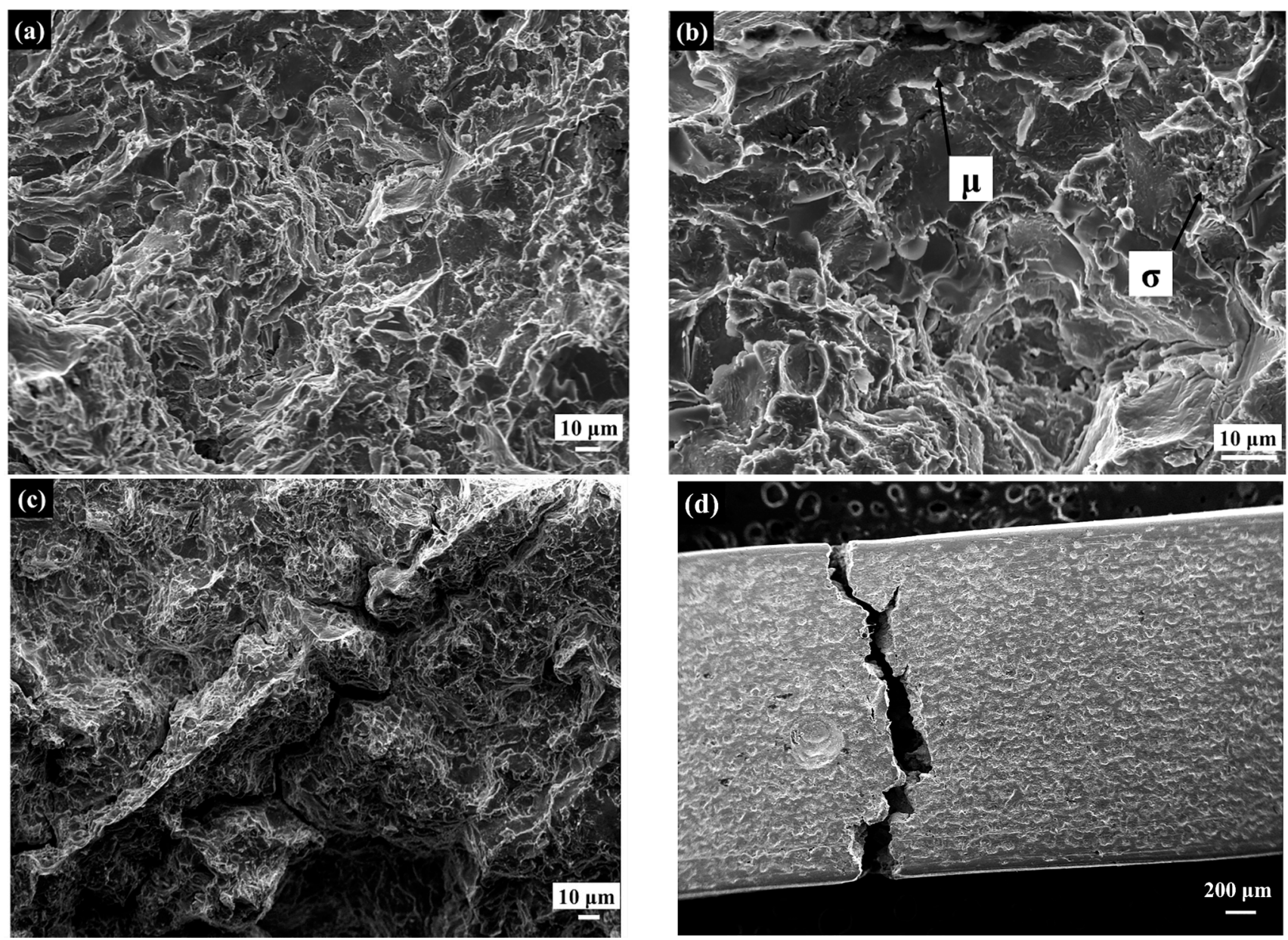

Figure 12. The fracture surface of the $\mathrm{Fe}_{40} \mathrm{Cr}_{15} \mathrm{Co}_{10} \mathrm{Mn}_{5} \mathrm{Ni}_{20} \mathrm{Mo}_{10}$ alloy: (a,b) Low and highmagnification images of the fracture surface, respectively; (c) Microcracks on the fracture surface; image $(\mathbf{d})$ is the macro morphology of the tensile specimen after the fracture.

\section{Discussion}

\subsection{Phase Formation, Stability, and Transition}

The five-component $\mathrm{Fe}_{40} \mathrm{Cr}_{15} \mathrm{Co}_{15} \mathrm{Mn}_{10} \mathrm{Ni}_{20}$ nonequiatomic high-entropy alloy shows a single-phase FCC structure, which does not conform to the Gibbs phase law under constant pressure [72], i.e., $\mathrm{F}=\mathrm{C}-\mathrm{P}+1$, in which $\mathrm{F}$ represents the degree of freedom, $\mathrm{C}$ represents the number of the component, and $\mathrm{P}$ represents the number of phases. This phenomenon is generally reported to be associated with the high-entropy effect [73]. According to Gibbs free energy formula (Equation (3) [15]), the increase of mixing entropy would reduce the Gibbs free energy of mixing, which is beneficial to the formation of a single-phase solid solution. In the formula, $\Delta G_{\text {mix }}$ is the Gibbs free energy of mixing, $\Delta H_{\text {mix }}$ is the enthalpy of mixing, and $\Delta S_{m i x}$ is the entropy of mixing.

$$
\Delta G_{\text {mix }}=\Delta H_{\text {mix }}-T \Delta S_{\text {mix }}
$$

The formula of mixing entropy (Equation (4) [74]) reveals that when the multiple principal elements are in equimolar or near-equimolar ratios, the mixing entropy increases with increasing the number of components, which assists the formation of a single-phase structure. In this formula, $R$ is the gas constant, and $n$ is the number of the principal elements.

$$
\Delta S_{\text {mix }}^{\max }=R \ln (n)
$$


The above discussion suggests that the high mixing entropy of the $\mathrm{Fe}_{40} \mathrm{Cr}_{15} \mathrm{Co}_{15} \mathrm{Mn}_{10} \mathrm{Ni}_{20}$ alloy has a positive effect on the formation of a single-phase solid solution, which is well acknowledged by many researchers at present [75]. However, the explanation has its limitations as several researchers pointed out that mixing enthalpy also had an important effect on the phase structure. For instance, Otto et al. and Singh et al. [76,77] both reported that mixing enthalpy showed a similar effect on the formation of solid solution phases for high-entropy alloys as compared with the mixing entropy. Tsai et al. suggested that the competition between entropy and enthalpy determined the phase formation [73].

For the phase stability of FeCrCoMnNi system high-entropy alloys, it is generally accepted that reducing the content of $\mathrm{Cr}$ and $\mathrm{Mn}$ to a suitable level is beneficial to avoid the formation of $\sigma$ phase and improve the stability of the FCC phase, whereas properly increasing $\mathrm{Co}$ and $\mathrm{Ni}$ will not only assist the formation of the FCC phase but also inhibit the appearance of the secondary phases [37-40]. He et al. studied the Co-Cr-Fe-Ni system high-entropy alloys using the CALPHAD method and experimental verification [37]. They found that the Co-Cr-Fe-Ni single-phase FCC high entropy alloy was stable when the contents of the $\mathrm{Co}, \mathrm{Fe}$, and $\mathrm{Ni}$ elements ranged from $20 \%$ to $40 \%$. However, the molar fraction of $\mathrm{Cr}$ should be lower than $25 \%$ to maintain the single FCC phase [37]. Bracq et al. investigated the phase stability of the FCC solid solution in the Co-Cr-Fe-Mn-Ni system using the Calphad approach [38]. It was found that the increasing contents of $\mathrm{Mn}$ and $\mathrm{Cr}$ destabilized the FCC solid solution, which was different from Ni and Co [38]. Recently, Cao et al. reported that the thermodynamic properties of the $\mathrm{AlCoCrFeNi}_{\mathrm{x}}(1.0 \leq \mathrm{x} \leq 1.8)$ were improved when the content of $\mathrm{Ni}$ was increased [39]. Zhu et al. studied the phase stability of $(\mathrm{FeNiCrMn})_{(100-x)} \mathrm{Co}_{x}(\mathrm{x}=5,10$ and 20$)$ high-entropy alloys using XRD, SEM and TEM techniques [40]. They found that all the alloys possessed a single FCC phase in the as-cast state, while the FCC phase stability was higher when $x=20$ as compared to $x=5$ and 10 [40]. Regarding the phase stability in the presence of Fe, Lee et al. reported that the addition of Fe stabilized the FCC phase in the $\mathrm{Al}_{0.5} \mathrm{CoCrFe}_{\mathrm{x}} \mathrm{NiTi}_{0.5}$ high-entropy alloys [78]. Zhang et al. analyzed the phase formation and transition of $\mathrm{Fe}_{\mathrm{x}} \mathrm{CoCrNiMn}$ high-entropy alloys [79]. The single FCC structure was determined with the Fe content of 10-60\%, while a BCC structure appeared when the Fe content was greater than $62 \%$. A similar phase transition trend was also reported by Qiu et al., for the Fe-containing high-entropy alloys [80]. The literature review suggests the stability of a single FCC structure could be achieved with a wide range of Fe content, whereas high contents of $\mathrm{Co}$ and $\mathrm{Ni}$ and low contents of $\mathrm{Cr}$ and Mn could be appropriate for the FCC phase stability. Moreover, the effect of $\mathrm{Ni}$ and $\mathrm{Co}$ on the formation of the FCC phase is similar and Ni has a stronger ability to form the FCC phase as compared to that of Co [41,42]. Hsu et al. constructed approximate phase diagrams for Al-Co-Cr-Fe-Mo-Ni system high-entropy alloys according to the results of SEM, TEM, XRD, and DTA analyses [81]. The phase diagrams demonstrated that the stabilized FCC solid solution can be formed when the content of Co was approaching $30 \%$, while the same effect was found for $\mathrm{Ni}$ at a lower content of $\sim 20 \%$. The above literature review supports that the design of cost-efficient nonequiatomic FeCrCoMnNi single-phase FCC high-entropy alloy can be achieved by increasing the contents of Fe and $\mathrm{Ni}$ and decreasing the contents of $\mathrm{Co}, \mathrm{Cr}$, and $\mathrm{Mn}$, which has been experimentally proved in this work.

According to the valence electron concentration (VEC) method proposed by Guo and Liu [82], the phase stabilization in high-entropy alloys could be predicted. The high-entropy alloy favors the formation of FCC-type solid solutions when VEC $\geq 8$, while it favors the formation of BCC-type solid solutions when VEC < 6.87 [83]. The VEC for high-entropy alloys can be defined as: VEC $=\sum_{i=1}^{n} c_{i}(\mathrm{VEC})_{i}$, where $n$ is the number of components in the alloy, $\mathrm{c}_{\mathrm{i}}$ and $(\mathrm{VEC})_{\mathrm{i}}$ are the atomic concentration and the VEC for the individual element, respectively. Given that the VECs for Fe, Cr, Co, Mn, Ni, Al and Mo are 8, 6, 9, 7, 10, 3 and 6 [82], the calculated VEC for the three investigated alloys are $8.15\left(\mathrm{Fe}_{40} \mathrm{Cr}_{15} \mathrm{Co}_{15} \mathrm{Mn}_{10} \mathrm{Ni}_{20}\right)$, $7.61\left(\mathrm{Fe}_{40} \mathrm{Cr}_{15} \mathrm{Co}_{10} \mathrm{Mn}_{4} \mathrm{Ni}_{20} \mathrm{Al}_{11}\right)$ and $7.95\left(\mathrm{Fe}_{40} \mathrm{Cr}_{15} \mathrm{Co}_{10} \mathrm{Mn}_{5} \mathrm{Ni}_{20} \mathrm{Mo}_{10}\right)$, respectively. The VEC results suggest that only the $\mathrm{Fe}_{40} \mathrm{Cr}_{15} \mathrm{Co}_{15} \mathrm{Mn}_{10} \mathrm{Ni}_{20}$ alloy could favor the formation 
of the single FCC phase, while the other two alloys may contain BCC or other secondary phases in addition to the FCC phase, which is consistent with the findings in this work.

For the $\mathrm{Fe}_{40} \mathrm{Cr}_{15} \mathrm{Co}_{10} \mathrm{Mn}_{4} \mathrm{Ni}_{20} \mathrm{Al}_{11}$ alloy, the addition of $\mathrm{Al}$ leads to the formation of the BCC phase in addition to the FCC matrix. In this system, the atomic radius of Fe $(1.26 \AA), \mathrm{Cr}(1.28 \AA), \mathrm{Co}(1.25 \AA), \mathrm{Mn}(1.26 \AA)$ and Ni $(1.24 \AA)$ is much smaller than that of $\mathrm{Al}(1.43 \AA)$ [53]. Thus, the addition of Al causes lattice distortion in the FCC phase as a result of the solid-solution strengthening effect [84]. The diffraction peaks of the FCC phase after adding $\mathrm{Al}$ are all shifted slightly to the negative direction with smaller $2 \theta$, suggesting the increased lattice constant after the $\mathrm{Al}$ addition, which has been verified by the analysis using the Bragg lattice equation (Equation (1) [54]). The calculated lattice parameter of the FCC matrix for $\mathrm{Fe}_{40} \mathrm{Cr}_{15} \mathrm{Co}_{10} \mathrm{Mn}_{4} \mathrm{Ni}_{20} \mathrm{Al}_{11}$ (3.60273 $\AA$ ) is increased as compared to the $\mathrm{Fe}_{40} \mathrm{Cr}_{15} \mathrm{Co}_{15} \mathrm{Mn}_{10} \mathrm{Ni}_{20}$ alloy (3.58420 $\mathrm{A}$ ). In addition, the $\mathrm{BCC}$ structure is more suitable to accommodate larger solute atoms such as $\mathrm{Al}$, because the $\mathrm{BCC}$ structure has a lower atomic packing density (68\%) as compared to that of the FCC structure (74\%) [29]. Therefore, it is rationalized that the addition of $\mathrm{Al}$ promotes the appearance of the $\mathrm{BCC}$ phase in the $\mathrm{Fe}_{40} \mathrm{Cr}_{15} \mathrm{Co}_{10} \mathrm{Mn}_{4} \mathrm{Ni}_{20} \mathrm{Al}_{11}$ alloy.

For the Mo-containing $\mathrm{Fe}_{40} \mathrm{Cr}_{15} \mathrm{Co}_{10} \mathrm{Mn}_{5} \mathrm{Ni}_{20} \mathrm{Mo}_{10}$ alloy, it consists of an FCC-structured matrix, a large number of $\mu-(\mathrm{Mo}, \mathrm{Cr})$ phases, and a small number of $\sigma-(\mathrm{Cr}, \mathrm{Mo})$ phases. It is reported that the addition of Mo together with $\mathrm{Cr}$ would readily cause the saturation of Mo in the FCC solid solution and lead to the formation of intermetallic compounds, which well explains the phase formation in this work [35,51]. Even though the atomic radius of Mo $(1.39 \AA)$ is slightly smaller than $\mathrm{Al}(1.43 \AA)$, its radius is larger than the other five elements in the system [53]. Thus, the diffraction peaks for the FCC matrix slightly shift to the left as expected, similar to that of the $\mathrm{Fe}_{40} \mathrm{Cr}_{15} \mathrm{Co}_{10} \mathrm{Mn}_{4} \mathrm{Ni}_{20} \mathrm{Al}_{11}$ alloy (Figure 2). The lattice parameter of the FCC matrix for the $\mathrm{Fe}_{40} \mathrm{Cr}_{15} \mathrm{Co}_{10} \mathrm{Mn}_{5} \mathrm{Ni}_{20} \mathrm{Mo}_{10}$ (3.60465 $\AA$ ) alloy is found to be larger than that of $\mathrm{Fe}_{40} \mathrm{Cr}_{15} \mathrm{Co}_{10} \mathrm{Mn}_{4} \mathrm{Ni}_{20} \mathrm{Al}_{11}$ (3.60273 $\AA$ ), suggesting a strong solution strengthening effect by the addition of Mo [30]. In addition, the $\sigma-(\mathrm{Cr}, \mathrm{Mo})$ phase tends to transform into $\mu$-(Mo, $\mathrm{Cr}$ ) phase to release the larger lattice strain caused by Mo when the content of Mo is high $[6,30,50]$. Generally, the phase transformation in the $\mathrm{FeCrCoMnNiMo}$ system high-entropy alloys is in the sequence of FCC $\rightarrow$ FCC $+\sigma \rightarrow$ FCC $+\sigma+\mu$ [49] when increasing the content of Mo. In this work, the results reveal that the secondary phases are mainly $\mu-(\mathrm{Mo}, \mathrm{Cr})$ phase accompanied by a small amount of $\sigma-(\mathrm{Cr}, \mathrm{Mo})$ phase, suggesting the occurrence of $\sigma \rightarrow \mu$ phase transformation.

\subsection{Mechanical Properties}

\subsubsection{Vickers Hardness}

$\mathrm{Fe}_{40} \mathrm{Cr}_{15} \mathrm{Co}_{15} \mathrm{Mn}_{10} \mathrm{Ni}_{20}$ alloy possesses a single FCC solid solution phase, which can be easily deformed when external stresses are applied [85], leading to lower hardness. After adding $\mathrm{Al}$ or Mo, the FCC-structured alloy could be strengthened via solid-solution strengthening, precipitation strengthening, etc. [86-88]. For the $\mathrm{Fe}_{40} \mathrm{Cr}_{15} \mathrm{Co}_{10} \mathrm{Mn}_{4} \mathrm{Ni}_{20} \mathrm{Al}_{11}$ alloy, the FCC/BCC dual-phase structure greatly enhances its hardness due to the strong deformation resistance of the BCC phase [89]. Joseph et al. [46] conducted nanoindentation tests on $\mathrm{Al}_{0.6} \mathrm{CoCrFeNi}$ high-entropy alloy and found that the hardness of the $\mathrm{BCC}$ phase was about 1.5 times higher than that of the FCC matrix, suggesting that the incorporation of harder BCC phase to the FCC matrix would largely enhance its hardness. Further, the results of $\mathrm{XRD}$ reveal that the addition of $\mathrm{Al}$ has a solution strengthening effect, leading to additional improvement in the hardness of the alloy. Regarding the $\mathrm{Fe}_{40} \mathrm{Cr}_{15} \mathrm{Co}_{10} \mathrm{Mn}_{5} \mathrm{Ni}_{20} \mathrm{Mo}_{10}$ alloy, the formation of intermetallic compounds $\mu$ and $\sigma$ are prevalent along grain boundaries and in the interior of grains. It has been well studied by Liu et al. [50] that the microhardness of the $\mu$ and $\sigma$ phases is five to six times higher than that of the FCC phase. Consequently, the substantial increase in hardness of the $\mathrm{Fe}_{40} \mathrm{Cr}_{15} \mathrm{Co}_{10} \mathrm{Mn}_{5} \mathrm{Ni}_{20} \mathrm{Mo}_{10}$ alloy is mainly related to the precipitation of the harder intermetallic compounds in addition to the solid-solution strengthening [86,90]. 


\subsubsection{Tensile Properties}

For the tensile properties, the ductility of the $\mathrm{Fe}_{40} \mathrm{Cr}_{15} \mathrm{Co}_{15} \mathrm{Mn}_{10} \mathrm{Ni}_{20}$ alloy is outstanding, although the $\sigma_{0.2}$ and UTS were relatively lower as a result of its single-phase FCC structure. The $\sigma_{0.2}(158 \pm 4 \mathrm{MPa})$, UTS $(420 \pm 20 \mathrm{MPa})$, and elongation at fracture $(53.4 \pm 3.4 \%)$ for the as-cast $\mathrm{Fe}_{40} \mathrm{Cr}_{15} \mathrm{Co}_{15} \mathrm{Mn}_{10} \mathrm{Ni}_{20}$ alloy are comparable and even superior to many of the traditional high-cost equiatomic FeCrCoMnNi high entropy alloys reported in the literature $[85,89,91-93]$. For the duplex FCC plus BCC structured $\mathrm{Fe}_{40} \mathrm{Cr}_{15} \mathrm{Co}_{10} \mathrm{Mn}_{4} \mathrm{Ni}_{20} \mathrm{Al}_{11}$ alloy, the $\sigma_{0.2}$ and UTS were remarkably improved, which is similar to the hardness, resulting from the incorporation of the harder BCC phase into the FCC matrix. Its ductility was only slightly reduced as a result of the presence of the secondary phases. This viewpoint has been confirmed by the Al-rich granular particles and shallower ductile dimples observed on the fractured surface of the $\mathrm{Fe}_{40} \mathrm{Cr}_{15} \mathrm{Co}_{10} \mathrm{Mn}_{4} \mathrm{Ni}_{20} \mathrm{Al}_{11}$ alloy (Figure 11b).

As for the $\mathrm{Fe}_{40} \mathrm{Cr}_{15} \mathrm{Co}_{10} \mathrm{Mn}_{5} \mathrm{Ni}_{20} \mathrm{Mo}_{10}$ alloy, the addition of Mo introduces a large number of brittle intermetallic compounds such as $\mu$ and $\sigma$ phases into the FCC matrix. This is detrimental to the ductility of the high-entropy alloy even though its yield strength could be improved because of the strong restriction of the dislocation movement by the existing intermetallic compounds. Qin et al. [70] reported that a large number of secondary phases would be formed in the $(\mathrm{CoCrFeMnNi})_{100-x} \mathrm{Mo}_{\mathrm{x}}$ high-entropy alloys when the Mo content was high than $8 \%$. The volume fraction of the secondary phases can be as high as $66 \%$ at the Mo content of $16 \%$. The yield strength of the alloy was found to improve due to the solution strengthening effect of the Mo element and the formation of secondary phases [70]. Since the intermetallic secondary phases are brittle in nature, the mechanical strength of the high-entropy alloy could be compromised as a result of the deteriorated ductility by increasing the volume fraction of the secondary phases. Liu et al. suggested that a suitable amount of Mo addition could obtain the best mechanical properties of the FeCoCrNiMo alloy with balanced achievement of strength and ductility [50]. However, a large amount of Mo addition would result in a severe degradation in the mechanical performance due to the overly high-volume fraction and brittle nature of $\mu$ precipitates [50]. In this work, the severe cracking observed on the fractured surface is attributed to the high-stress concentration at the interface of the secondary phase/FCC matrix where the dislocation accumulation is high during the tensile testing (Figure 12) [94,95]. The cracking of the brittle intermetallic compound should not be ignored, which would act as the preferential sites for crack nucleation and lead to premature fracture of the $\mathrm{Fe}_{40} \mathrm{Cr}_{15} \mathrm{Co}_{10} \mathrm{Mn}_{5} \mathrm{Ni}_{20} \mathrm{Mo}_{10}$ alloy $[51,88,95]$. These findings collaboratively support that the premature brittle fracture and deteriorated tensile strength were attributed to the existence of excessive intermetallic compounds and their resultant microcrack nucleation in the alloy. Thus, the addition of Mo should be controlled at a suitable amount by which the tensile strength can be improved through solution strengthening and precipitation strengthening while its ductility can be largely maintained.

It is well acknowledged that the mechanical properties of the high-entropy alloys are highly dependent on their microstructures. The formation of secondary phases in the FCC matrix by the addition of $\mathrm{Al}$ and Mo has greatly improved the hardness and yield strength of the prepared alloys. In order to further understand the relationship between the microstructure and mechanical properties, the volume fractions of the secondary phases were evaluated using Photoshop software, as shown in Figures 13 and 14. At least three different SEM images were used to obtain the average value of the volume fraction. The estimated volume fractions of the secondary phases for $\mathrm{Fe}_{40} \mathrm{Cr}_{15} \mathrm{Co}_{10} \mathrm{Mn}_{4} \mathrm{Ni}_{20} \mathrm{Al}_{11}$ and $\mathrm{Fe}_{40} \mathrm{Cr}_{15} \mathrm{Co}_{10} \mathrm{Mn}_{5} \mathrm{Ni}_{20} \mathrm{Mo}_{10}$ alloys are $9.0 \pm 1.0 \%$ and $15.8 \pm 0.9 \%$, respectively. 


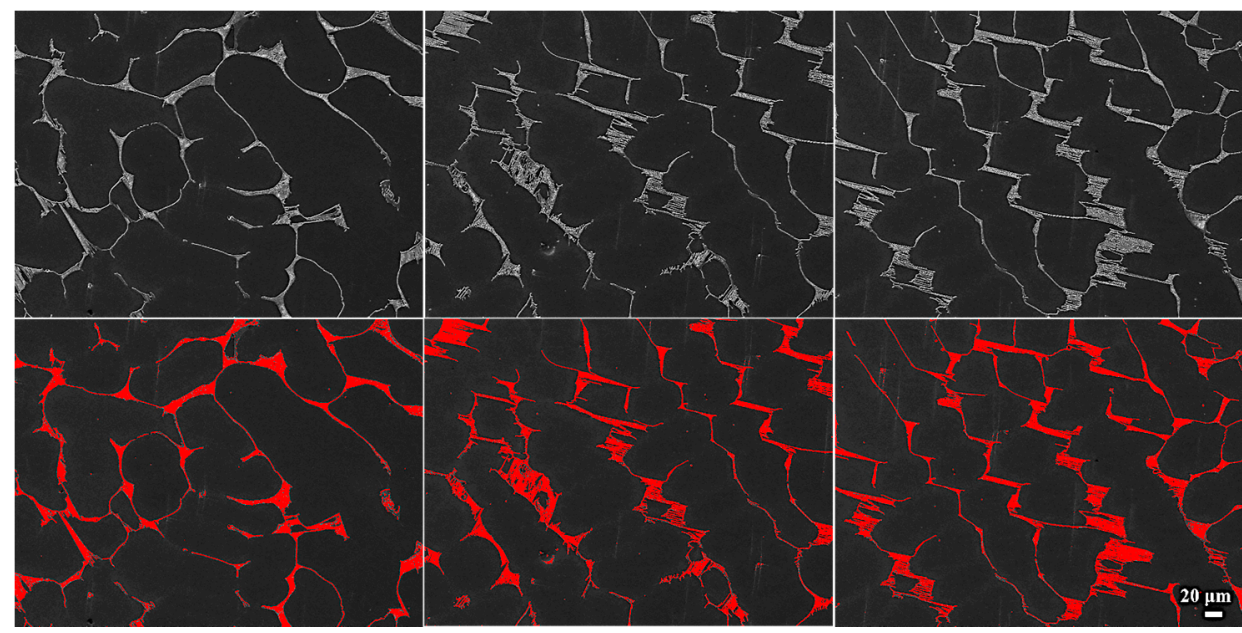

Figure 13. Sketch maps for evaluating the volume fraction of the BCC phases in $\mathrm{Fe}_{40} \mathrm{Cr}_{15} \mathrm{Co}_{10} \mathrm{Mn}_{4} \mathrm{Ni}_{20} \mathrm{Al}_{11}$ alloy using Photoshop software. The upper three images are the initial SEM observations; the lower three images show the corresponding regions marked in red for analysis.

For the duplex FCC plus BCC structured AlxFeCrCoMnNi high-entropy alloys ( $\mathrm{Al}$ content is $8-11$ at.\%), the strength or hardness generally linearly increases with the increase of the volume fraction of BCC $[29,44,48,84]$. The strength of the alloys can be estimated by the simple rule-of-mixture [29], i.e., $\sigma=\sigma_{F C C}^{*} V_{F C C}+\sigma_{B C C}^{*} V_{B C C}=\sigma_{F C C}^{*}+\left(\sigma_{B C C}^{*}-\sigma_{F C C}^{*}\right) V_{B C C}$ (Equation (5)), in which $V_{F C C}+V_{B C C}=1, \sigma_{F C C}^{*}$ and $V_{F C C}$ are the strength and volume fraction of the FCC phase, $\sigma_{B C C}^{*}$ and $V_{B C C}$ are the strength and volume fraction of the BCC phase, respectively. Note that the BCC phase is much stronger than the FCC phase (i.e., $\sigma_{B C C}^{*}-\sigma_{F C C}^{*}>0$ ), suggesting the strength linearly increases with the volume fraction of $\mathrm{BCC}\left(V_{B C C}\right)$ as per Equation (5). In this work, the estimated volume fraction of BCC for Fe40Cr15Co10Mn4Ni20Al11 alloy is $9.0 \pm 1.0 \%$, while its yield strength and tensile strength are increased from $158 \pm 4 \mathrm{MPa}$ and $420 \pm 20 \mathrm{MPa}$ to $218 \pm 7 \mathrm{MPa}$ and $507 \pm 16 \mathrm{MPa}$, respectively, as compared to the single-phase FCC structure Fe40Cr15Co15Mn10Ni20 alloy. This indicates the formation of the BCC phase by the addition of $\mathrm{Al}$ can remarkably strengthen the prepared high-entropy alloys.

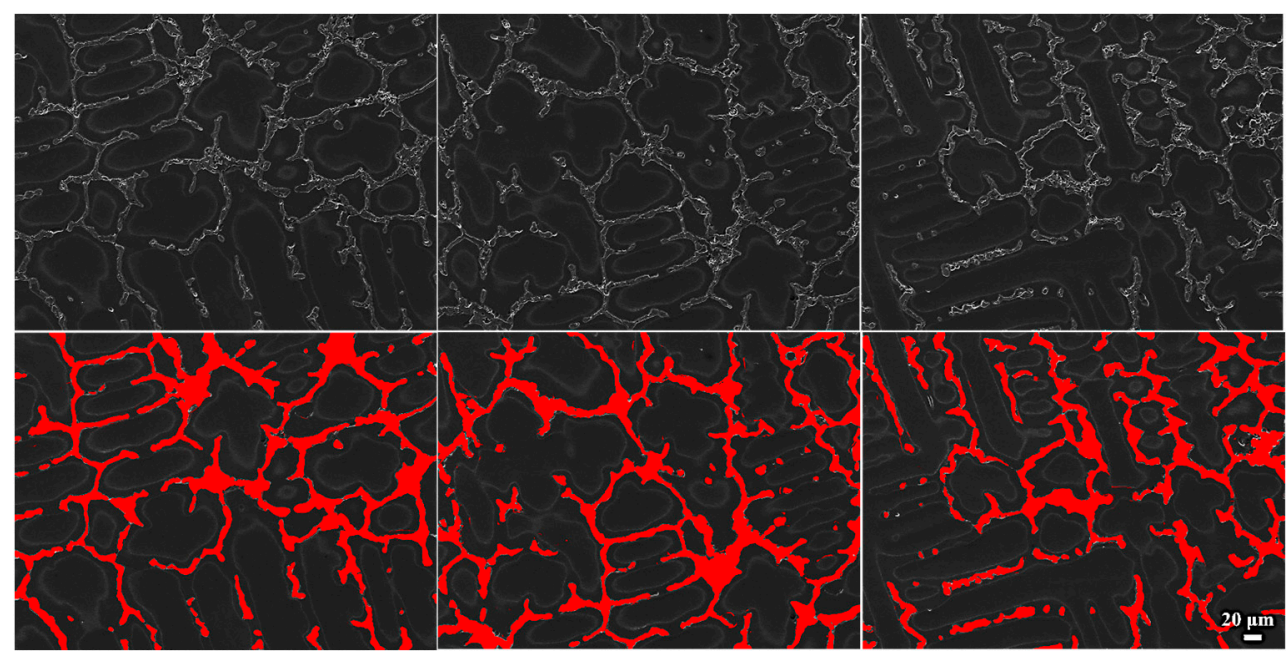

Figure 14. Sketch maps for evaluating the volume fraction of the intermetallic compounds (such as $\mu$ and $\sigma$ phases) in $\mathrm{Fe}_{40} \mathrm{Cr}_{15} \mathrm{Co}_{10} \mathrm{Mn}_{5} \mathrm{Ni}_{20} \mathrm{Mo}_{10}$ alloy using Photoshop software. The upper three images are the initial SEM observations; the lower three images show the corresponding regions marked in red for analysis. 
Qin et al. determined that the simple rule-of-mixture can still be used to describe the strength of the CoCrFeMnNiMox high-entropy alloys (Mo content is 0-16 at.\%), i.e., $\sigma=\sigma_{F C C}^{*}+\left(\sigma_{i}^{*}-\sigma_{F C C}^{*}\right) V_{i}$ (Equation (6)) [70]. In this equation, $\sigma_{F C C}^{*}$ and $\sigma_{i}^{*}$ are the strength of the FCC and intermetallic compounds, $V_{i}$ stands for the volume fraction of the intermetallic compounds. Similar to the analysis of the $\mathrm{Fe}_{40} \mathrm{Cr}_{15} \mathrm{Co}_{10} \mathrm{Mn}_{4} \mathrm{Ni}_{20} \mathrm{Al}_{11}$ alloy, the strength should linearly increase with the volume fraction of the intermetallic compounds as long as the intermetallic compounds are stronger than the FCC phases (i.e., $\sigma_{i}^{*}-\sigma_{F C C}^{*}>0$ ). In this investigation, the estimated volume fraction of the intermetallic compounds for the $\mathrm{Fe}_{40} \mathrm{Cr}_{15} \mathrm{Co}_{10} \mathrm{Mn}_{5} \mathrm{Ni}_{20} \mathrm{Mo}_{10}$ alloy is $15.8 \pm 0.9 \%$. Its yield strength is $246 \pm 15 \mathrm{MPa}$, which is much higher than the single-phase FCC structure $\mathrm{Fe}_{40} \mathrm{Cr}_{15} \mathrm{Co}_{15} \mathrm{Mn}_{10} \mathrm{Ni}_{20}$ alloy $(158 \pm 4 \mathrm{MPa})$ and the $\mathrm{FCC}+$ BCC structure $\mathrm{Fe}_{40} \mathrm{Cr}_{15} \mathrm{Co}_{10} \mathrm{Mn}_{4} \mathrm{Ni}_{20} \mathrm{Al}_{11}$ alloy $(218 \pm 7 \mathrm{MPa})$. However, its tensile strength is only $346 \pm 15 \mathrm{MPa}$, which is lower than both the $\mathrm{Fe}_{40} \mathrm{Cr}_{15} \mathrm{Co}_{15} \mathrm{Mn}_{10} \mathrm{Ni}_{20}(420 \pm 20 \mathrm{MPa})$ and $\mathrm{Fe}_{40} \mathrm{Cr}_{15} \mathrm{Co}_{10} \mathrm{Mn}_{4} \mathrm{Ni}_{20} \mathrm{Al}_{11}(507 \pm 16 \mathrm{MPa})$. It suggests that the formation of intermetallic compounds could significantly improve the yield strength, which is consistent with Equation (6). However, the tensile strength cannot be evaluated by Equation (6), which might be attributed to the fact that the intermetallic compounds are too brittle to be deformed under tensile loading.

It is generally acknowledged that the single-phase FCC-structured high-entropy alloys exhibit excellent ductility with low strength whereas single-phase BCC-structured high-entropy alloys show high strength with low ductility [96,97]. The combination of ductile FCC-matrix and a suitable amount of strong BCC phases would be a good strategy to design high-entropy alloys with high strength and good ductility [98]. Many researchers are designing and fabricating high-entropy alloys consisting of a principal FCC phase with strong secondary phases, such as BCC-phases, nano precipitates, etc., which could remarkably increase the mechanical strength and maintain a good ductility $[67,99]$. The results of this work support that incorporating a small amount of strong BCC-structured secondary phases into the ductile FCC matrix could achieve the optimized strength/hardness and ductility, such as the Al-reinforced $\mathrm{Fe}_{40} \mathrm{Cr}_{15} \mathrm{Co}_{10} \mathrm{Mn}_{4} \mathrm{Ni}_{20} \mathrm{Al}_{11}$ alloy. However, a large number of strong secondary phases, especially those brittle intermetallic compounds, such as the $\mu$ and $\sigma$ intermetallic compounds in the Mo-containing $\mathrm{Fe}_{40} \mathrm{Cr}_{15} \mathrm{Co}_{10} \mathrm{Mn}_{5} \mathrm{Ni}_{20} \mathrm{Mo}_{10}$ alloy as reported herein, are detrimental to the improvement of the mechanical properties. The findings of this investigation are not only beneficial to the research of traditional high-entropy alloys but also critical to the follow-up studies of the newly designed nonequiatomic high-entropy alloys.

\section{Conclusions}

In this work, a Fe-rich nonequiatomic $\mathrm{Fe}_{40} \mathrm{Cr}_{15} \mathrm{Co}_{15} \mathrm{Mn}_{10} \mathrm{Ni}_{20}$ high-entropy alloy was successfully prepared, and the influence of $\mathrm{Al}$ or Mo addition on the microstructure and mechanical properties was investigated. The following conclusions can be drawn.

(1) $\mathrm{Fe}_{40} \mathrm{Cr}_{15} \mathrm{Co}_{15} \mathrm{Mn}_{10} \mathrm{Ni}_{20}$ high-entropy alloy was a single-phase face-centered cubic (FCC) structure, whereas the Al-containing $\mathrm{Fe}_{40} \mathrm{Cr}_{15} \mathrm{Co}_{10} \mathrm{Mn}_{4} \mathrm{Ni}_{20} \mathrm{Al}_{11}$ alloy was a duplex FCC plus BCC structure owing to the lattice distortion as a result of the incorporation of $\mathrm{Al}$. With the addition of $\mathrm{Mo}$, a large number of $(\mathrm{Mo}, \mathrm{Cr})$-rich $\mu$ phases and few $(\mathrm{Cr}, \mathrm{Mo})$-rich $\sigma$ phases were introduced to the $\mathrm{Fe}_{40} \mathrm{Cr}_{15} \mathrm{Co}_{10} \mathrm{Mn}_{5} \mathrm{Ni}_{20} \mathrm{Mo}_{10}$ alloy.

(2) The $\mathrm{Fe}_{40} \mathrm{Cr}_{15} \mathrm{Co}_{15} \mathrm{Mn}_{10} \mathrm{Ni}_{20}$ nonequiatomic high-entropy alloy exhibited moderate strength and excellent ductility owing to its single-phase FCC structure. After the addition of $\mathrm{Al}$, the formation of less deformable BCC phases in the $\mathrm{Fe}_{40} \mathrm{Cr}_{15} \mathrm{Co}_{10} \mathrm{Mn}_{4} \mathrm{Ni}_{20} \mathrm{Al}_{11}$ alloy remarkably increased its hardness, yield strength $\left(\sigma_{0.2}\right)$, and UTS, without compromising its ductility significantly. For the $\mathrm{Fe}_{40} \mathrm{Cr}_{15} \mathrm{Co}_{10} \mathrm{Mn}_{5} \mathrm{Ni}_{20} \mathrm{Mo}_{10}$ alloy, the existence of a large number of intermetallic compounds (mainly $\mu$ phase and a small amount of $\sigma$ phase) significantly deteriorated its UTS and ductility, even though the hardness and $\sigma_{0.2}$ could be improved. Therefore, it is crucial to control the quantity of the brittle intermetallic compounds to develop high-entropy alloys with high strength/hardness and good ductility. 


\begin{abstract}
Author Contributions: Conceptualization, S.W. (Shuliang Wang) and S.W. (Shidong Wang); methodology, S.W. (Shuliang Wang) and S.W. (Shidong Wang); software, L.C.; validation, L.C.; formal analysis, S.W. (Shuliang Wang), L.C. and S.W. (Shidong Wang); investigation, L.C.; resources, S.W. (Shuliang Wang); data curation, L.C.; writing—original draft preparation, S.W. (Shuliang Wang), L.C. and S.W. (Shidong Wang); writing-review and editing, S.W. (Shidong Wang), Q.L., M.W., S.Y. and D.X.; supervision, S.W. (Shuliang Wang) and S.W. (Shidong Wang); project administration, S.W. (Shuliang Wang) and S.W. (Shidong Wang); funding acquisition, S.W. (Shuliang Wang). All authors have read and agreed to the published version of the manuscript.
\end{abstract}

Funding: This research was funded by Guangxi Key Laboratory of Information Materials (Guilin University of Electronic Technology), P.R. China, grant number 191009-K.

Institutional Review Board Statement: Not applicable.

Informed Consent Statement: Not applicable.

Data Availability Statement: The data sets used or analyzed during the current study are available from the corresponding author upon reasonable request.

Acknowledgments: This work was supported by Guangxi Key Laboratory of Information Materials (Guilin University of Electronic Technology), P.R. China (Project No. 191009-K).

Conflicts of Interest: The authors declare no conflict of interest.

\title{
References
}

1. Han, S.Z.; Choi, E.-A.; Lim, S.H.; Kim, S.; Lee, J. Alloy design strategies to increase strength and its trade-offs together. Prog. Mater. Sci. 2021, 117, 100720. [CrossRef]

2. Benvenuto, M.A. Metals and Alloys: Industrial Applications; De Gruyter: Berlin, Germany, 2016.

3. Gupta, M. Changing Wisdom of Metallic Alloys Development. Mater. Sci. Appl. 2018, 9, 1021. [CrossRef]

4. Yeh, J.-W. Alloy Design Strategies and Future Trends in High-Entropy Alloys. Jom 2013, 65, 1759-1771. [CrossRef]

5. Zhang, Q.; Li, M.Y.; Han, B.; Zhang, S.Y.; Li, Y.; Hu, C.Y. Investigation on microstructures and properties of $\mathrm{Al}_{1.5} \mathrm{CoCrFeMnNi}$ high entropy alloy coating before and after ultrasonic impact treatment. J. Alloys Compd. 2021, 884, 160989. [CrossRef]

6. Ming, K.; Bi, X.; Wang, J. Precipitation strengthening of ductile $\mathrm{Cr}_{15} \mathrm{Fe}_{20} \mathrm{Co}_{35} \mathrm{Ni}_{20} \mathrm{Mo}_{10}$ alloys. Scr. Mater. 2017, 137, 88-93. [CrossRef]

7. Klaver, T.P.C.; Simonovic, D.; Sluiter, M.H.F. Brute Force Composition Scanning with a CALPHAD Database to Find Low Temperature Body Centered Cubic High Entropy Alloys. Entropy 2018, 20, 911. [CrossRef]

8. Sanin, V.N.; Yukhvid, V.I.; Ikornikov, D.M.; Andreev, D.E.; Sachkova, N.V.; Alymov, M.I. SHS metallurgy of high-entropy transition metal alloys. Dokl. Phys. Chem. 2016, 470, 145-149. [CrossRef]

9. Zhao, D.; Yang, Q.; Wang, D.; Yan, M.; Wang, P.; Jiang, M.; Liu, C.; Diao, D.; Lao, C.; Chen, Z.; et al. Ordered nitrogen complexes overcoming strength-ductility trade-off in an additively manufactured high-entropy alloy. Virtual Phys. Prototyp. 2020, 15, 532-542. [CrossRef]

10. Yeh, J.W.; Chen, S.K.; Lin, S.J.; Gan, J.Y.; Chin, T.S.; Shun, T.T.; Tsau, C.H.; Chang, S.Y. Nanostructured High-Entropy Alloys with Multiple Principal Elements: Novel Alloy Design Concepts and Outcomes. Adv. Eng. Mater. 2004, 6, 299-303. [CrossRef]

11. Amar, A.; Li, J.; Xiang, S.; Liu, X.; Zhou, Y.; Le, G.; Wang, X.; Qu, F.; Ma, S.; Dong, W.; et al. Additive manufacturing of high-strength CrMnFeCoNi-based High Entropy Alloys with TiC addition. Intermetallics 2019, 109, 162-166. [CrossRef]

12. Li, J.-H.; Tsai, M.-H. Theories for predicting simple solid solution high-entropy alloys: Classification, accuracy, and important factors impacting accuracy. Scr. Mater. 2020, 188, 80-87. [CrossRef]

13. Gorbachev, I.I.; Popov, V.V.; Katz-Demyanetz, A.; Popov, V.; Eshed, E. Prediction of the Phase Composition of High-Entropy Alloys Based on Cr-Nb-Ti-V-Zr Using the Calphad Method. Phys. Met. Metallogr. 2019, 120, 378-386. [CrossRef]

14. Ren, M.-X.; Li, B.-S.; Fu, H.-Z. Formation condition of solid solution type high-entropy alloy. Trans. Nonferrous Met. Soc. China 2013, 23, 991-995. [CrossRef]

15. Luan, H.-W.; Shao, Y.; Li, J.-F.; Mao, W.-L.; Han, Z.-D.; Shao, C.; Yao, K.-F. Phase stabilities of high entropy alloys. Scr. Mater. 2020, 179, 40-44. [CrossRef]

16. Li, S.; Cong, D.; Sun, X.; Zhang, Y.; Chen, Z.; Nie, Z.; Li, R.; Li, F.; Ren, Y.; Wang, Y. Wide-temperature-range perfect superelasticity and giant elastocaloric effect in a high entropy alloy. Mater. Res. Lett. 2019, 7, 482-489. [CrossRef]

17. Han, Z.H.; Liang, S.; Yang, J.; Wei, R.; Zhang, C.J. A superior combination of strength-ductility in CoCrFeNiMn high-entropy alloy induced by asymmetric rolling and subsequent annealing treatment. Mater. Charact. 2018, 145, 619-626. [CrossRef]

18. Jin, X.; Gu, X.; Quan, F.; Ran, X.; Zhang, K.; Mao, A. CoCrFeMnNi high-entropy alloy powder with excellent corrosion resistance and soft magnetic property prepared by gas atomization method. Mater. Werkst. 2019, 50, 837-843. [CrossRef]

19. Xia, A.; Franz, R. Thermal Stability of MoNbTaVW High Entropy Alloy Thin Films. Coatings 2020, 10, 941. [CrossRef]

20. Zhang, C.Y.; Yue, B.B.; Bhandari, U.; Starovoytov, O.N.; Yang, Y.; Young, D.P.; Yan, J.Y.; Hong, F.; Yang, S.Z. In situ study on the compression deformation of MoNbTaVW high-entropy alloy. J. Alloy. Compd. 2021, 871, 159557. [CrossRef] 
21. Chiu, C.T.; Teng, Y.J.; Dai, B.H.; Tsao, I.Y.; Lin, W.C.; Wang, K.W.; Hsu, L.C.; Chang, Y.C.; Li, C.T.; Nguyen, H.T.T.; et al. Novel high-entropy ceramic/carbon composite materials for the decomposition of organic pollutants. Mater. Chem. Phys. 2022, $275,125274$. [CrossRef]

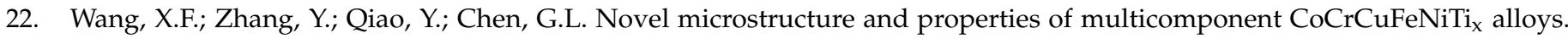
Intermetallics 2007, 15, 357-362. [CrossRef]

23. Han, Y.; Li, H.; Feng, H.; Li, K.; Tian, Y.; Jiang, Z. Enhancing the strength and ductility of CoCrFeMnNi high-entropy alloy by nitrogen addition. Mater. Sci. Eng. A 2020, 789, 139587. [CrossRef]

24. Borkar, T.; Gwalani, B.; Choudhuri, D.; Mikler, C.V.; Yannetta, C.J.; Chen, X.; Ramanujan, R.V.; Styles, M.J.; Gibson, M.A.; Banerjee, R. A combinatorial assessment of $\mathrm{Al}_{x} \mathrm{CrCuFeNi}_{2}(0<\mathrm{x}<1.5)$ complex concentrated alloys: Microstructure, microhardness, and magnetic properties. Acta Mater. 2016, 116, 63-76. [CrossRef]

25. Cui, W.; Zhang, X.; Li, L.; Chen, Y.; Liou, F. Fabrication and Characterization of $\mathrm{Al}_{\mathrm{x}} \mathrm{CrCuFeNi}_{2}$ High-Entropy Alloys Coatings by Laser Metal Deposition. Procedia Manuf. 2019, 39, 509-518. [CrossRef]

26. Laplanche, G.; Horst, O.; Otto, F.; Eggeler, G.; George, E.P. Microstructural evolution of a CoCrFeMnNi high-entropy alloy after swaging and annealing. J. Alloy. Compd. 2015, 647, 548-557. [CrossRef]

27. Kwon, H.; Moon, J.; Bae, J.W.; Park, J.M.; Son, S.; Do, H.-S.; Lee, B.-J.; Kim, H.S. Precipitation-driven metastability engineering of carbon-doped CoCrFeNiMo medium-entropy alloys at cryogenic temperature. Scr. Mater. 2020, 188, 140-145. [CrossRef]

28. Lukianova, O.A.; Rao, Z.; Kulitckii, V.; Li, Z.; Wilde, G.; Divinski, S.V. Impact of interstitial carbon on self-diffusion in CoCrFeMnNi high entropy alloys. Scr. Mater. 2020, 188, 264-268. [CrossRef]

29. He, J.Y.; Liu, W.H.; Wang, H.; Wu, Y.; Liu, X.J.; Nieh, T.G.; Lu, Z.P. Effects of Al addition on structural evolution and tensile properties of the FeCoNiCrMn high-entropy alloy system. Acta Mater. 2014, 62, 105-113. [CrossRef]

30. Shun, T.-T.; Chang, L.-Y.; Shiu, M.-H. Microstructure and mechanical properties of multiprincipal component CoCrFeNiMox alloys. Mater. Charact. 2012, 70, 63-67. [CrossRef]

31. Lu, Y.; Dong, Y.; Guo, S.; Jiang, L.; Kang, H.; Wang, T.; Wen, B.; Wang, Z.; Jie, J.; Cao, Z.; et al. A Promising New Class of High-Temperature Alloys: Eutectic High-Entropy Alloys. Sci. Rep. 2014, 4, 6200. [CrossRef]

32. Wani, I.S.; Bhattacharjee, T.; Sheikh, S.; Lu, Y.P.; Chatterjee, S.; Bhattacharjee, P.P.; Guo, S.; Tsuji, N. Ultrafine-Grained $\mathrm{AlCoCrFeNi}_{2.1}$ Eutectic High-Entropy Alloy. Mater. Res. Lett. 2016, 4, 174-179. [CrossRef]

33. Mishra, R.S.; Haridas, R.S.; Agrawal, P. High entropy alloys-Tunability of deformation mechanisms through integration of compositional and microstructural domains. Mater. Sci. Eng. A 2021, 812, 141085. [CrossRef]

34. Chen, C.; Pang, S.; Cheng, Y.; Zhang, T. Microstructure and mechanical properties of $\mathrm{Al}_{20-x} \mathrm{Cr}_{20+0.5 x} \mathrm{Fe}_{20} \mathrm{Co}_{20} \mathrm{Ni}_{20+0.5 x}$ high entropy alloys. J. Alloy. Compd. 2016, 659, 279-287. [CrossRef]

35. Tasan, C.C.; Deng, Y.; Pradeep, K.G.; Yao, M.J.; Springer, H.; Raabe, D. Composition Dependence of Phase Stability, Deformation Mechanisms, and Mechanical Properties of the CoCrFeMnNi High-Entropy Alloy System. Jom 2014, 66, 1993-2001. [CrossRef]

36. Bae, J.W.; Park, J.M.; Moon, J.; Choi, W.M.; Lee, B.-J.; Kim, H.S. Effect of $\mu$-precipitates on the microstructure and mechanical properties of non-equiatomic CoCrFeNiMo medium-entropy alloys. J. Alloy. Compd. 2019, 781, 75-83. [CrossRef]

37. He, F.; Wang, Z.; Wu, Q.; Niu, S.; Li, J.; Wang, J.; Liu, C.T. Solid solution island of the Co-Cr-Fe-Ni high entropy alloy system. Scr. Mater. 2017, 131, 42-46. [CrossRef]

38. Bracq, G.; Laurent-Brocq, M.; Perrière, L.; Pirès, R.; Joubert, J.-M.; Guillot, I. The fcc solid solution stability in the Co-Cr-Fe-Mn-Ni multi-component system. Acta Mater. 2017, 128, 327-336. [CrossRef]

39. Cao, L.; Wang, X.; Wang, Y.; Zhang, L.; Yang, Y.; Liu, F.; Cui, Y. Microstructural evolution, phase formation and mechanical properties of multi-component AlCoCrFeNix alloys. Appl. Phys. A 2019, 125, 699. [CrossRef]

40. Zhu, Z.G.; Ma, K.H.; Yang, X.; Shek, C.H. Annealing effect on the phase stability and mechanical properties of (FeNiCrMn)(100-)Co high entropy alloys. J. Alloy. Compd. 2017, 695, 2945-2950. [CrossRef]

41. Zhang, L.; Zhang, Y. Tensile Properties and Impact Toughness of $\mathrm{AlCo}_{\mathrm{x}} \mathrm{CrFeNi}_{3.1-\mathrm{x}}(\mathrm{x}=0.4,1)$ High-Entropy Alloys. Front. Mater 2020, 7, 92. [CrossRef]

42. Ke, G.-Y.; Chen, G.-Y.; Hsu, T.; Yeh, J.-W. FCC and BCC equivalents in as-cast solid solutions of $\mathrm{Al} \mathrm{CCoyCrzCu_{0.5 }} \mathrm{FevNN}_{\mathrm{N}}$ high-entropy alloys. Eur. J. Control 2006, 31, 669-684. [CrossRef]

43. Wei, S.; He, F.; Tasan, C.C. Metastability in high-entropy alloys: A review. J. Mater. Res. 2018, 33, 2924-2937. [CrossRef]

44. Kao, Y.-F.; Chen, T.-J.; Chen, S.-K.; Yeh, J.-W. Microstructure and mechanical property of as-cast, -homogenized, and -deformed $\mathrm{Al}_{\mathrm{x}} \mathrm{CoCrFeNi}(0 \leq \mathrm{x} \leq 2)$ high-entropy alloys. J. Alloy. Compd. 2009, 488, 57-64. [CrossRef]

45. Rao, J.C.; Diao, H.Y.; Ocelík, V.; Vainchtein, D.; Zhang, C.; Kuo, C.; Tang, Z.; Guo, W.; Poplawsky, J.D.; Zhou, Y.; et al. Secondary phases in $\mathrm{Al}_{\mathrm{x}} \mathrm{CoCrFeNi}$ high-entropy alloys: An in-situ TEM heating study and thermodynamic appraisal. Acta Mater. 2017, 131, 206-220. [CrossRef]

46. Joseph, J.; Stanford, N.; Hodgson, P.; Fabijanic, D.M. Understanding the mechanical behaviour and the large strength/ductility differences between FCC and BCC $\mathrm{Al}_{x} \mathrm{CoCrFeNi}$ high entropy alloys. J. Alloy. Compd. 2017, 726, 885-895. [CrossRef]

47. Aizenshtein, M.; Priel, E.; Hayun, S. Effect of pre-deformation and $\mathrm{B} 2$ morphology on the mechanical properties of $\mathrm{Al}_{0.5} \mathrm{CoCrFeNi}$ HEA. Mater. Sci. Eng. A 2020, 788, 139575. [CrossRef]

48. Wang, W.-R.; Wang, W.-L.; Wang, S.-C.; Tsai, Y.-C.; Lai, C.-H.; Yeh, J.-W. Effects of Al addition on the microstructure and mechanical property of $\mathrm{Al}_{\mathrm{x}} \mathrm{CoCrFeNi}$ high-entropy alloys. Intermetallics 2012, 26, 44-51. [CrossRef] 


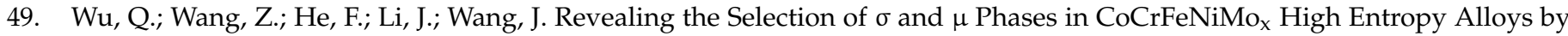
CALPHAD. J. Phase Equilibria Diffus. 2018, 39, 446-453. [CrossRef]

50. Liu, Y.; Xie, Y.; Cui, S.; Yi, Y.; Xing, X.; Wang, X.; Li, W. Effect of Mo Element on the Mechanical Properties and Tribological Responses of $\mathrm{CoCrFeNiMo}$ High-Entropy Alloys. Metals 2021, 11, 486. [CrossRef]

51. Liu, W.H.; Lu, Z.P.; He, J.Y.; Luan, J.H.; Wang, Z.J.; Liu, B.; Liu, Y.; Chen, M.W.; Liu, C.T. Ductile CoCrFeNiMox high entropy alloys strengthened by hard intermetallic phases. Acta Mater. 2016, 116, 332-342. [CrossRef]

52. Yang, S.; Liu, Z.; Pi, J. Microstructure and wear behavior of the AlCrFeCoNi high-entropy alloy fabricated by additive manufacturing. Mater. Lett. 2020, 261, 127004. [CrossRef]

53. Zhang, Y.; Jiang, X.; Sun, H.; Shao, Z. Effect of annealing heat treatment on microstructure and mechanical properties of nonequiatomic CoCrFeNiMo medium-entropy alloys prepared by hot isostatic pressing. Nanotechnol. Rev. 2020, 9, 580-595. [CrossRef]

54. Gevaux, D. The equation to bridge worlds. Nature 2014, 511, 6-7. [CrossRef]

55. Zhang, M.; Yao, L.; Zhu, M.; Liu, Y.; Jian, Z. Structural Evolution and Mechanical and Magnetic Properties of Nonequiatomic $\mathrm{CoFe}_{2} \mathrm{NiMn}_{0.3} \mathrm{Al}_{\mathrm{x}}(0.25 \leq \mathrm{x} \leq 1.00)$ High-Entropy Alloys. J. Mater. Eng. Perform. 2021, 30, 1472-1478. [CrossRef]

56. Han, J.; Su, B.; Lu, J.; Meng, J.; Zhang, A.; Wu, Y. Preparation of MoNbTaW refractory high entropy alloy powders by pressureless spark plasma sintering: Crystal structure and phase evolution. Intermetallics 2020, 123, 106832. [CrossRef]

57. Laurent-Brocq, M.; Perrière, L.; Pirès, R.; Prima, F.; Vermaut, P.; Champion, Y. From diluted solid solutions to high entropy alloys: On the evolution of properties with composition of multi-components alloys. Mater. Sci. Eng. A 2017, 696, 228-235. [CrossRef]

58. Denton, A.R.; Ashcroft, N.W. Vegard's law. Phys. Rev. A 1991, 43, 3161-3164. [CrossRef]

59. Chizmeshya, A.V.G.; Bauer, M.R.; Kouvetakis, J. Experimental and Theoretical Study of Deviations from Vegard's Law in the $\mathrm{Sn}_{\mathrm{x}} \mathrm{Ge}_{1-\mathrm{x}}$ System. Chem. Mater. 2003, 15, 2511-2519. [CrossRef]

60. Alonso, J.C.; Alonso, O.C. Derivation of unit cell volume, and lattice parameter of cubic high entropy alloys from volume size factors. Intermetallics 2021, 137, 107299. [CrossRef]

61. Pulikkotil, J.J.; Chroneos, A.; Schwingenschlögl, U. Structure of $\mathrm{Sn}_{1-\mathrm{x}} \mathrm{Ge}_{\mathrm{x}}$ random alloys as obtained from the coherent potential approximation. J. Appl. Phys. 2011, 110, 036105. [CrossRef]

62. Risti, R.; Figueroa, I.A.; Feti, A.S.; Zadro, K.; Babi, E. Transition from high-entropy to conventional $(\mathrm{TiZrNbCu})_{1-\mathrm{x}} \mathrm{Co}_{\mathrm{x}} \mathrm{metallic}$ glasses. J. Appl. Phys. 2021, 130, 195102. [CrossRef]

63. Kuo, Y.-K.; Liou, B.-T.; Yen, S.-H.; Chu, H.-Y. Vegard's law deviation in lattice constant and band gap bowing parameter of zincblende $\mathrm{In}_{\mathrm{x}} \mathrm{Ga}_{1-\mathrm{x}} \mathrm{N}$. Opt. Commun. 2004, 237, 363-369. [CrossRef]

64. Zhang, C.; Zhang, F.; Jin, K.; Bei, H.; Chen, S.; Cao, W.; Zhu, J.; Lv, D. Understanding of the Elemental Diffusion Behavior in Concentrated Solid Solution Alloys. J. Phase Equilibria Diffus. 2017, 38, 434-444. [CrossRef]

65. Ye, F.; Jiao, Z.; Yan, S.; Guo, L.; Feng, L.; Yu, J. Microbeam plasma arc remanufacturing: Effects of Al on microstructure, wear resistance, corrosion resistance and high temperature oxidation resistance of $\mathrm{Al}_{\mathrm{x}} \mathrm{CoCrFeMnNi}$ high-entropy alloy cladding layer. Vacuum 2020, 174, 109178. [CrossRef]

66. Yuan, Y.; Xu, Z.; Han, P.; Dan, Z.; Qin, F.; Chang, H. $\mathrm{MnO}_{2}$-decorated metallic framework supercapacitors fabricated from duplex-phase $\mathrm{FeCrCoMnNiAl}{ }_{0.75}$ Cantor high entropy alloy precursors through selective phase dissolution. J. Alloy. Compd. 2021, 870, 159523. [CrossRef]

67. Wu, M.; Chen, K.; Xu, Z.; Li, D.Y. Effect of Ti addition on the sliding wear behavior of AlCrFeCoNi high-entropy alloy. Wear 2020, 462, 203493. [CrossRef]

68. Manzoni, A.; Daoud, H.; Mondal, S.; van Smaalen, S.; Völkl, R.; Glatzel, U.; Wanderka, N. Investigation of phases in $\mathrm{Al}_{23} \mathrm{Co}_{15} \mathrm{Cr}_{23} \mathrm{Cu}_{8} \mathrm{Fe}_{15} \mathrm{Ni}_{16}$ and $\mathrm{Al}_{8} \mathrm{Co}_{17} \mathrm{Cr}_{17} \mathrm{Cu}_{8} \mathrm{Fe}_{17} \mathrm{Ni}_{33}$ high entropy alloys and comparison with equilibrium phases predicted by Thermo-Calc. J. Alloy. Compd. 2013, 552, 430-436. [CrossRef]

69. Niu, Z.; Wang, Y.; Geng, C.; Xu, J.; Wang, Y. Microstructural evolution, mechanical and corrosion behaviors of as-annealed $\mathrm{CoCrFeNiMo}_{\mathrm{x}}(\mathrm{x}=0,0.2,0.5,0.8,1)$ high entropy alloys. J. Alloy. Compd. 2020, 820, 153273. [CrossRef]

70. Qin, G.; Chen, R.; Zheng, H.; Fang, H.; Wang, L.; Su, Y.; Guo, J.; Fu, H. Strengthening FCC-CoCrFeMnNi high entropy alloys by Mo addition. J. Mater. Sci. Technol. 2019, 35, 578-583. [CrossRef]

71. Zhu, J.M.; Fu, H.M.; Zhang, H.F.; Wang, A.M.; Li, H.; Hu, Z.Q. Microstructures and compressive properties of multicomponent AlCoCrFeNiMox alloys. Mater. Sci. Eng. A 2010, 527, 6975-6979. [CrossRef]

72. Zhou, Y.J.; Zhang, Y.; Kim, T.N.; Chen, G.L. Microstructure characterizations and strengthening mechanism of multi-principal component $\mathrm{AlCoCrFeNiTi}{ }_{0.5}$ solid solution alloy with excellent mechanical properties. Mater. Lett. 2008, 62, 2673-2676. [CrossRef]

73. Tsai, M.-H.; Yeh, J.-W. High-Entropy Alloys: A Critical Review. Mater. Res. Lett. 2014, 2, 107-123. [CrossRef]

74. Wang, S. Paracrystalline property of high-entropy alloys. AIP Adv. 2013, 3, 102105. [CrossRef]

75. Tong, Z.; Ren, X.; Jiao, J.; Zhou, W.; Ren, Y.; Ye, Y.; Larson, E.A.; Gu, J. Laser additive manufacturing of FeCrCoMnNi high-entropy alloy: Effect of heat treatment on microstructure, residual stress and mechanical property. J. Alloy. Compd. 2019, 785, 1144-1159. [CrossRef]

76. Otto, F.; Yang, Y.; Bei, H.; George, E.P. Relative effects of enthalpy and entropy on the phase stability of equiatomic high-entropy alloys. Acta Mater. 2013, 61, 2628-2638. [CrossRef]

77. Singh, S.; Wanderka, N.; Murty, B.S.; Glatzel, U.; Banhart, J. Decomposition in multi-component AlCoCrCuFeNi high-entropy alloy. Acta Mater. 2011, 59, 182-190. [CrossRef] 
78. Lee, C.-F.; Shun, T.-T. Effect of Fe content on microstructure and mechanical properties of $\mathrm{Al}_{0.5} \mathrm{CoCrFe}_{\mathrm{x}} \mathrm{NiTi}_{0.5} \mathrm{high}_{-\mathrm{entropy}}$ alloys. Mater. Charact. 2016, 114, 179-184. [CrossRef]

79. Zhang, T.; Xin, L.; Wu, F.; Zhao, R.; Xiang, J.; Chen, M.; Jiang, S.; Huang, Y.; Chen, S. Microstructure and mechanical properties of $\mathrm{Fe}_{\mathrm{x}} \mathrm{CoCrNiMn}$ high-entropy alloys. J. Mater. Sci. Technol. 2019, 35, 2331-2335. [CrossRef]

80. Qiu, H.; Zhu, H.; Zhang, J.; Xie, Z. Effect of Fe content upon the microstructures and mechanical properties of Fe $\mathrm{C}_{\mathrm{x}} \mathrm{NiCu}$ high entropy alloys. Mater. Sci. Eng. A 2020, 769, 138514. [CrossRef]

81. Hsu, C.-Y.; Juan, C.-C.; Chen, S.-T.; Sheu, T.-S.; Yeh, J.-W.; Chen, S.-K. Phase Diagrams of High-Entropy Alloy System Al-Co-Cr-Fe-Mo-Ni. JOM 2013, 65, 1829-1839. [CrossRef]

82. Guo, S.; Liu, C.T. Phase stability in high entropy alloys: Formation of solid-solution phase or amorphous phase. Prog. Nat. Sci. Mater. Int. 2011, 21, 433-446. [CrossRef]

83. Guo, S.; Ng, C.; Lu, J.; Liu, C. Effect of valence electron concentration on stability of fcc or bcc phase in high entropy alloys. J. Appl. Phys. 2011, 109, 103505. [CrossRef]

84. Li, M.; Zhang, Q.; Han, B.; Song, L.; Li, J.; Yang, J. Investigation on microstructure and properties of $\mathrm{Al}_{\mathrm{x}} \mathrm{CoCrFeMnNi}$ high entropy alloys by ultrasonic impact treatment. J. Alloy. Compd. 2020, 816, 152626. [CrossRef]

85. $\mathrm{Gu}, \mathrm{J} . ; \mathrm{Ni}$, S.; Liu, Y.; Song, M. Regulating the strength and ductility of a cold rolled FeCrCoMnNi high-entropy alloy via annealing treatment. Mater. Sci. Eng. A 2019, 755, 289-294. [CrossRef]

86. Bracq, G.; Laurent-Brocq, M.; Varvenne, C.; Perrière, L.; Curtin, W.A.; Joubert, J.M.; Guillot, I. Combining experiments and modeling to explore the solid solution strengthening of high and medium entropy alloys. Acta Mater. 2019, 177, 266-279. [CrossRef]

87. Wang, S.D.; Xu, D.K.; Chen, X.B.; Han, E.H.; Dong, C. Effect of heat treatment on the corrosion resistance and mechanical properties of an as-forged Mg-Zn-Y-Zr alloy. Corros. Sci. 2015, 92, 228-236. [CrossRef]

88. Wang, S.D.; Xu, D.K.; Wang, B.J.; Sheng, L.Y.; Qiao, Y.X.; Han, E.H.; Dong, C. Influence of phase dissolution and hydrogen absorption on the stress corrosion cracking behavior of $\mathrm{Mg}-7 \% \mathrm{Gd}-5 \% \mathrm{Y}-1 \% \mathrm{Nd}-0.5 \% \mathrm{Zr}$ alloy in $3.5 \mathrm{wt}$ \% $\mathrm{NaCl}$ solution. Corros. Sci. 2018, 142, 185-200. [CrossRef]

89. Huo, W.; Zhou, H.; Fang, F.; Hu, X.; Xie, Z.; Jiang, J. Strain-rate effect upon the tensile behavior of CoCrFeNi high-entropy alloys. Mater. Sci. Eng. A 2017, 689, 366-369. [CrossRef]

90. Wang, S.D.; Xu, D.K.; Wang, B.J.; Han, E.H.; Dong, C. Effect of solution treatment on the fatigue behavior of an as-forged Mg-Zn-Y-Zr alloy. Sci. Rep. 2016, 6, 23955. [CrossRef]

91. Choi, N.; Lim, K.R.; Na, Y.S.; Glatzel, U.; Park, J.H. Characterization of non-metallic inclusions and their influence on the mechanical properties of a FCC single-phase high-entropy alloy. J. Alloy. Compd. 2018, 763, 546-557. [CrossRef]

92. Otto, F.; Dlouhý, A.; Somsen, C.; Bei, H.; Eggeler, G.; George, E.P. The influences of temperature and microstructure on the tensile properties of a CoCrFeMnNi high-entropy alloy. Acta Mater. 2013, 61, 5743-5755. [CrossRef]

93. Kim, J.H.; Lim, K.R.; Won, J.W.; Na, Y.S.; Kim, H.-S. Mechanical properties and deformation twinning behavior of as-cast CoCrFeMnNi high-entropy alloy at low and high temperatures. Mater. Sci. Eng. A 2018, 712, 108-113. [CrossRef]

94. Liu, K.; Komarasamy, M.; Gwalani, B.; Shukla, S.; Mishra, R.S. Fatigue behavior of ultrafine grained triplex Al0.3CoCrFeNi high entropy alloy. Scr. Mater. 2019, 158, 116-120. [CrossRef]

95. Wang, S.D.; Xu, D.K.; Wang, B.J.; Han, E.H.; Dong, C. Effect of corrosion attack on the fatigue behavior of an as-cast Mg-7\%Gd$5 \%$ Y $1 \%$ Nd-0.5\%Zr alloy. Mater. Des. 2015, 84, 185-193. [CrossRef]

96. Wu, Z.; Bei, H.; Pharr, G.M.; George, E.P. Temperature dependence of the mechanical properties of equiatomic solid solution alloys with face-centered cubic crystal structures. Acta Mater. 2014, 81, 428-441. [CrossRef]

97. Senkov, O.N.; Senkova, S.V.; Woodward, C. Effect of aluminum on the microstructure and properties of two refractory highentropy alloys. Acta Mater. 2014, 68, 214-228. [CrossRef]

98. Jin, X.; Zhou, Y.; Zhang, L.; Du, X.; Li, B. A novel Fe 20 Co 20 Ni 41 Al 19 eutectic high entropy alloy with excellent tensile properties. Mater. Lett. 2018, 216, 144-146. [CrossRef]

99. Fu, Z.Q.; Jiang, L.; Wardini, J.L.; MacDonald, B.E.; Wen, H.M.; Xiong, W.; Zhang, D.L.; Zhou, Y.Z.; Rupert, T.J.; Chen, W.P.; et al. A high-entropy alloy with hierarchical nanoprecipitates and ultrahigh strength. Sci. Adv. 2018, 4, eaat8712. [CrossRef] 